\title{
Inside the system-wide cultural district: a new relational and organisational taxonomy of cultural districts based on the sector policies by Italian Regions (2000-2015)
}

\author{
Anna Maria Colavitti@i and Alessia Usai ${ }^{*}$ (i)
}

\begin{abstract}
A considerable environmental turbulence pushes cultural and creative firms to cluster and to adopt new forms of cross-integration. An issue common also to wider entrepreneurial ecosystems (EEs) of SMEs. This evolutionary trend has given birth to a new generation of cultural districts defined as system-wide cultural districts (SWCDs) in which culture acts like a lever for all production sectors and not merely the cultural one, as in the past. The paper investigates the internal nested geographies of SWCDs through a comparative analysis of the district policies implemented by Italian Regions from 2000 to 2015 providing a new classification of cultural districts that updates the existing ones and reflecting on the links between SWCDs, urban policies and landscape planning.
\end{abstract}

Keywords: System-wide cultural district, Cultural districts, Italian regions, Heritage management, Urban regeneration

\section{Introduction}

In the Nineties and early 2000s, the industrial district has been reshaped for the cultural production according to the studies on cultural districts and creativity. In spite of this, it is still difficult to talk about a perfect coincidence between productive and organizational models of the cultural district and those of the classical industrial district because cultural and creative industries mainly deal with immaterial goods and services, and because not all the territories have a cultural and natural heritage able to guarantee an "economy of valorization" with the same levels of production, employment and income of traditional industries. It is possible in art cities like Rome, Florence or Venice. The massive cultural tourism in Venice, however, teaches that even the "economy of valorisation" can be counterproductive if not accompanied by

\footnotetext{
*Correspondence: alessiausai@gmail.com

Department of Civil and Environmental Engineering

and Architecture-DICAAR, University of Cagliari, Via Santa Croce, 67, 09124 Cagliari, Italy
}

a clear urban strategy aimed at residents, investors and visitors (Santagata 2002, 2006; Salvemini 2008; Sacco et al. 2013a; Lazzeretti 2013; Palmi 2013; Comunian et al. 2014; Bertacchini and Segre 2016; Hutton 2016; Ponzini 2016).

Culture and art, considered in their broadest meaning, represent an essential input for the cultural district design (Throsby 2001). However, new elements have emerged in last years: the quality of life; the presence of creative practitioners and talents; the inclination towards innovation in the transition towards a cognitive-cultural capitalism; the cognitive capacity and the motivational re-orientation, i.e. the expansion of the individual experiences (functioning) and alternatives (capability) (Porter 1990; Sen 1992, 1999; Florida 2002; Porter 2003; Scott 2014).

In contemporary cultural districts the learning processes are linked to the simultaneous action of endogenous and exogenous factors, related to globalisation, which are completely foreign to the classical industrial district by Marshall and Becattini as well as to the 


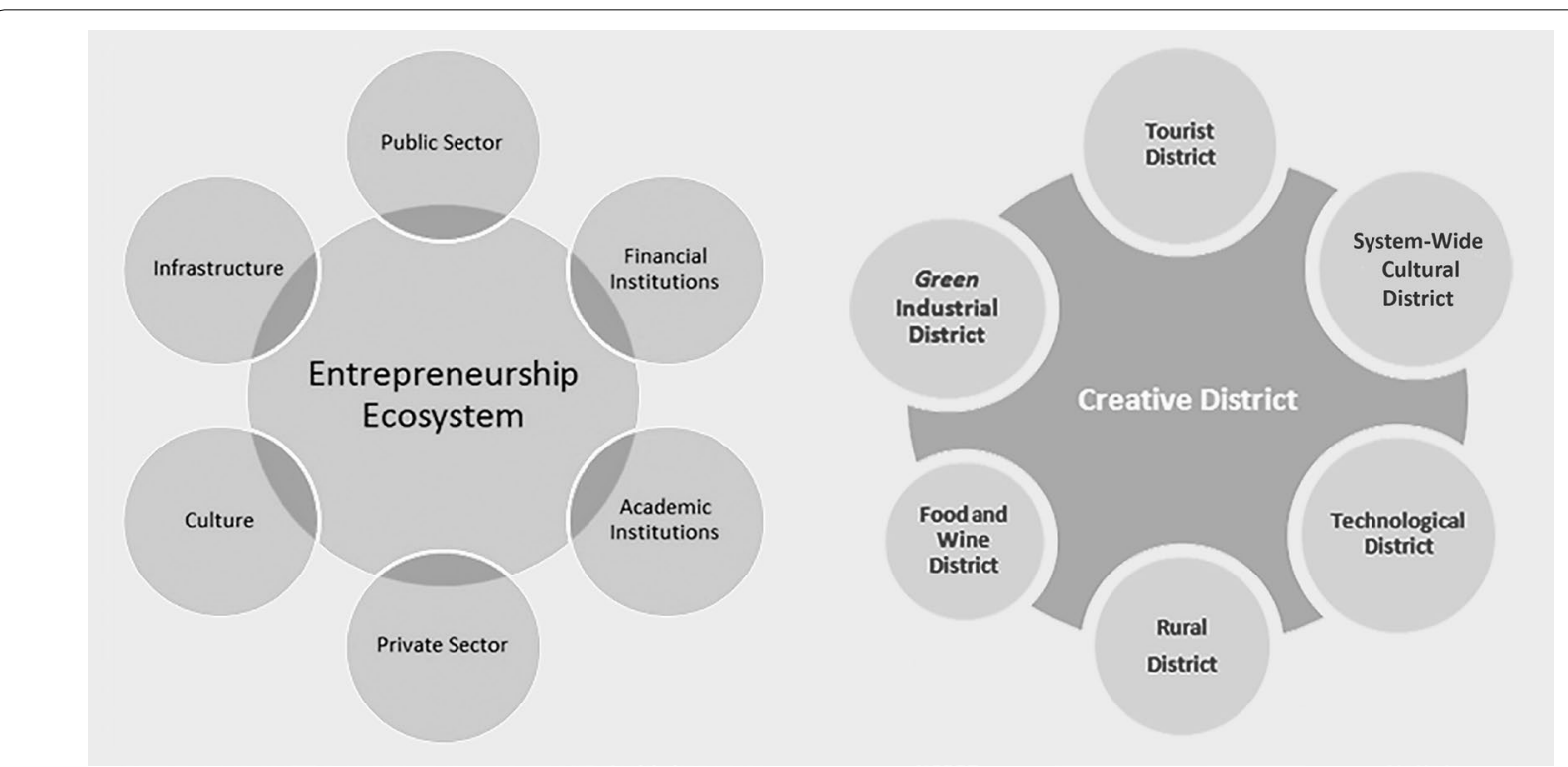

Fig. 1 The ecosystem model applied to SMEs in economic studies on innovation and to cultural/creative ecosystems: the nested geographies of EE and SWCD (Source: elaboration of the authors on Brown and Mason (2017) and Usai (2016b))

cultural district theorized by Valentino, Santagata and Sacco (Sacco et al. 2013a, b; Della Corte et al. 2018; Markwick 2018).

A considerable environmental turbulence pushes districts to build supra-local cluster supporting the local entrepreneurial networks (groups of enterprises, networks of enterprises, network enterprises), to adopt new forms of cross-integration, which go beyond the vertical and horizontal cooperation between different levels of the same hierarchical management system (Wellman and Hampton 1999; Robertson 1992; Bauman 1998; Sen 1999; Wellman and Hampton 2002; Feiock et al. 2008; Kim and Aguilera 2015; Brown and Mason 2017; Esposito and Rigby 2018; Habersetzera et al. 2018; Mudambi et al. 2018).

In innovation studies on SMEs, new systemic approaches have been applied to shed light on these agglomerative forces shaping the concept of entrepreneurial ecosystem (EE), i.e. a spatial concentration of economic activities where entrepreneurs are drawn to and, inextricably bound together, with other core entrepreneurial actors in close geographic, institutional and relational proximity (Brown and Mason 2017). Every EE is characterised by spatial boundedness, non-linear evolutionary thinking and multi-scale interactions on different spatial levels, both domestically and internationally. This implies organisational flexibility and nested geographies (i.e. EEs located within larger EEs). Thus, in the EE both agency (i.e. characteristics and behaviours of individuals and firms) and structure (i.e. the context regulating firms' behaviour, choices, and performance) must be examined together to fully appreciate the entrepreneurial dynamics in any given context (Brown and Mason 2017).

While conceptually and intuitively appealing, the EE concept presents some criticisms. For instance, Brown and Mason (2017) question the common understanding of EE concept. According to the authors, it has not been subjected to sufficient rigorous theoretical and empirical scrutiny due to a myopic focus on agency by scholars and policy makers. In this direction, the authors propose a general definition and classification for EEs claiming for further research in this direction (see Fig. 1).

Within this research line on SMEs, it can be placed the system-wide cultural district model (SWCD) developed by Sacco et al. (2013a, b, c) for the culture and creative sector. The SWCD relies on a new approach to local development where cultural production and participation have significant strategic complementarities with other production chains. In this view, culture drives the accumulation of intangible assets such as human, social, and cultural/symbolic capital, thereby fostering socioeconomic growth and environmental sustainability. The SWCD considers culture as a lever to enhance the local system's capacity to produce, circulate, and access information and symbolic content giving a competitive advantage to the members, even if they belong to different production chains and sectors.

A notion of cultural district which is no longer limited to the activities of cultural players per se. Compare to the "traditional" cultural district, in fact, the SWCD aims at 
the construction of dense, solid networks that allow local actors to join forces around a common developmental vision: "The cultural and creative sector thus acts as a regulator of local growth dynamics [...] in addition to being of course a complex system in itself" (Sacco et al. 2013a, p. 562).

Similarly to the EE, the SWCD needs a more rigorous theoretical and empirical analysis: the literature on district's performance concentrates mainly on the physical and tangible assets and on the beneficiaries of urban regeneration projects leaving on the background the forms of capital whose accumulation it facilitates (Howkins 2010; Belussi and Staber 2011; Sacco et al. 2013a, b, c; Seddio 2013; Scott 2014; Ferilli et al. 2016; Ponzini 2016; Nuccio and Ponzini 2017).

Analysing the first season of district policies in Italian Regions, Alberti and Giusti (2009), Barbetta et al. (2013), Palmi (2013) and Usai (2016a, b) shed some light on the organisational and relational nature of entrepreneurial networks forming the SWCD but they state the need for a supplementary work.

Our paper investigates on this issue exploring the nested geographies of SWCD in order to provide a more detailed picture about the cultural networks working inside cultural districts.

The paper is structured as follows. The first session illustrates the Italian contribution to the international debate on cultural districts pointing out the quest for more adequate taxonomies. In the second session, after an overview on the national urban policies on creativity and culture-which represent the research context, a comparative and qualitative analysis of the policies for cultural districts adopted by Italian regions from 2000 to 2015 is carried out. The comparison is based on a framework built on Santagata (2002), Alberti and Giusti (2009), Hinna and Seddio (2013), Seddio (2013) and Usai (2016a). Lastly, we reflect on the findings making general considerations regarding the absence of nested geographies in Italian SWCDs and the opportunity to re-consider cultural district as an umbrella concept under which put cultural networks involved in urban policies. In this view, we propose a new classification of cultural networks according to their relational and organizational features which update the taxonomies developed by Santagata $(2002,2006,2010)$ and by Sacco et al. $(2006,2013 a, b$, c), helpful for both the Italian and the international context.

\section{The international debate on cultural districts: the relational models adopted by cultural networks to establish links with the hosting cities and the SWCD model}

The location choices of cultural networks at urban level and the factors of the urban environment which contribute to attracting and retaining the creative class as well as to cultivating the creative talents of the local community, are key factors for the development of cultural and creative industries at urban level (Lazzeretti 2012, 2013; Comunian et al. 2014; Hutton 2016, p. 107). Thus, neo-liberal urban policies are the most investigated in research for cultural and creative industries, in particular those related to competitive bidding, to economic incentives for cultural firms, to territorial marketing and place branding, and to culture-led/creative-led urban regeneration strategies (including big events) (Sager 2011; Scott 2014).

Considering these policies, different approaches are emerging worldwide towards cultural networks and the links they establish with the hosting city.

In countries where institutions and public organisations show a dual attitude towards cultural and creative industries (considered a new element of welfare and at the same time an economic sector to develop), cultural networks are analyzed according to the purpose of their interventions. This approach puts the networks which support social inclusion in contrast with those supporting entrepreneurship (social purpose vs. economic purpose). It investigates the conflicts and the frictions between citizens and entrepreneurs and how they influence the interventions of urban requalification in one direction or another. This approach is common in the Anglo-Saxon world (United Kingdom, Australia, and United States) and in Asia (Stevenson 2014).

In Canada, France, Belgium and, for some aspects, even in Australia, cultural networks are investigated on the base of the top-down or bottom-up nature of their projects while, in post-colonial or post-communist countries (Australia, South Korea, Hong Kong, Singapore, and Baltic Republics), cultural networks and clusters are often studied considering the adherence of interventions to the culture of local communities (Mercer 2008). In this case, the studies on cultural and creative industries focus on: the ideologies and the narratives that permeate the policies destined to or produced by cultural networks; their relations with the pre-existing cultural and creative systems and their social impacts on local communities. Usually these studies operate on the following distinction: (1) authority-led initiatives which do not take local identity into consideration (China, South Korea); (2) initiatives which include local identity in the project through a participative planning of goals and interventions (Europe, Canada, Australia) (Ferilli et al. 2016; Girard et al. 2016).

Finally, differences between cluster- and district-oriented approaches are emerging according to the local production systems. In the English-speaking contexts of the U.S. and the UK, the economic dimension of cultural networks is the dominant one and the cluster model tends to prevail. Vice versa, in contexts with a prevalence 
of small family-owned firms such as Taiwan or Italy, the district model overcomes and the social and economic dimensions of cultural networks are equally important. Here the social fabric is the keystone that keeps the production system together, particularly in the case of SMEs linked by personal or family ties (Sacco et al. 2013b).

In Italy the innovation studies on SMEs and the concept of Entrepreneurial Ecosystem (EE) by Brown and Mason (2017) as well as the creative ecology/creative ecosystem idea by Howkins (2010) and Belussi and Staber (2011), have a deep impact on the cultural and creative sector. Cultural districts register a general shift from an organizational model which was mainly urban (cultural precincts, concerning the neighbourhood or the quarter), to a regional one involving different types of actors and spaces joined together in a "system of systems". This new cultural district is analysed and governed through the archetype of the system-wide cultural district (SWCD) ${ }^{1}$ (Sacco et al. 2013a, b, c). A productive and relational model based on the Third Italy experience and characterized by openness and inclusivity but also by nested geographies yet to be investigated.

Next paragraph illustrates the Italian contribution in this direction. It offers an insight on the SWCD model, the entrepreneurial networks working inside it, and the nested geographies that our paper aims to address.

\section{The Italian contribution to the international debate: new taxonomies for cultural districts and the entrepreneurial networks working inside them}

In Italy the first formulations of cultural district found place in Valentino et al. (1999) and Santagata (2000), this latter preceded by an article in the Giornale dell'Arte in 1999.

The cultural district models proposed in these publications, very different from each other. Analyzing the relationships with the tourist field, Valentino (2001, 2003) defines the "planned" cultural district as a geographically limited system of relations which integrates the valorisation of cultural heritage, both tangible and intangible, with the infrastructures and productive sectors necessary to it (Valentino 2001, p. 3). In such district heritage valorisation is an important "lever" for local development while the historical-artistic and environmental assets represent the "nodes" for its constitution. The model elaborated by Valentino (2003) provides interesting points for a new interpretation of the industrial district

\footnotetext{
1 The original wording in Italian by Sacco et al. (2013a) is distretto culturale evoluto but in English it has been translated in different ways. For example, Della Corte et al. (2018) acknowledge the SWCD as "evolved cultural district" while Usai (2016b) as "advanced cultural district".
}

as a network ${ }^{2}$ (Hinna and Seddio 2013, p. 37). Hence, the economic and corporate vision of the neoclassical theory leaves space for a new approach focused on the socio-cultural dimension of the district offering a solid theoretic base for the "advanced" or "creative" industrial district (Palmi 2013, p. 59).

Walter Santagata $(2002,2006,2010)$ proposed a new taxonomy for the cultural districts able to coordinate the Italian model with the Anglo-Saxon one, obtaining a huge response on an international level (Table 1). According to Santagata, the Anglo-Saxon district model is characterized by the focus on production (cultural and creative industries) and on agglomeration processes-natural or generated through policy actions. The best representative types of districts are the cultural district and the metropolitan one. On the contrary, in the Italian context, an institutional intervention, more or less marked, is expected. The district focus is on cultural heritage and its chain (preservation, valorization, usability, communication) and on the cognitive function of the territory, in agreement with the socio-technical dimension of Becattini's district model. Therefore, the most representative types of district are the institutional cultural district and the museum one. Santagata's work highlighted two research lines which still prevail in the Italian debate on cultural districts: the natural and voluntary mechanisms that induce enterprises to aggregation and, on the other hand, the institutional (artificial) mechanisms able to influence and encourage these processes.

In 2005 the cultural district models by Valentino and Santagata find an enrichment and a synthesis in the report "Culture and local development" by the OECD, where also a first collection of case studies is carried out. The report identifies: (1) heritage or museum districts created in response to tourist demand; (2) metropolitan cultural districts as an extension of the museum districts at an urban scale; (3) cultural districts resulting from the geographical clustering and the organisation of production within an area (e.g. Hollywood); (4) cultural and creative districts created by the associations of local artists and craftsmen; (5) cultural districts based on territorial brands, designations of origin and property rights on local textiles, furniture, agricultural products and wine in order to protect and promote the producers and the territory of production globally (here the report cites Santagata) (OECD 2005, pp. 106-110).

In the same years, Pier Luigi Sacco confirms the existence of two research paths, one linked to production and another linked to policy making. Using the concept of

\footnotetext{
${ }^{2}$ A qualifying network above all for medium, small, and micro enterprises that, alone, would not be able to compete on a global scale (Palmi 2013).
} 
Table 1 Classification of cultural districts according to the economic-institutional features. Source: elaboration of the authors on Santagata (2002) and Hinna and Seddio (2013)

\begin{tabular}{|c|c|c|c|c|c|}
\hline \multirow[t]{2}{*}{ Typologies } & \multicolumn{5}{|c|}{ Characteristics } \\
\hline & Model & $\begin{array}{l}\text { Role of public } \\
\text { administrations }\end{array}$ & Sectors involved & Positive externalities & $\begin{array}{l}\text { Protection of intellectual } \\
\text { property }\end{array}$ \\
\hline Industrial cultural district & Natural & $\begin{array}{l}\text { Definition of develop- } \\
\text { ment trajectories (no } \\
\text { explicit public policy) }\end{array}$ & $\begin{array}{l}\text { Design, audiovisual, } \\
\text { cinema, fashion }\end{array}$ & Related to production & $\begin{array}{l}\text { Patents, industrial secrets, } \\
\text { tacit knowledge, trade- } \\
\text { marks }\end{array}$ \\
\hline $\begin{array}{l}\text { Institutional cultural } \\
\text { district }\end{array}$ & Semi-planned & $\begin{array}{l}\text { Attribution of brands } \\
\text { and property rights }\end{array}$ & $\begin{array}{l}\text { Culture of "savoir vivre", } \\
\text { fairs and exhibitions on } \\
\text { agrifood industry and } \\
\text { certified products }\end{array}$ & $\begin{array}{l}\text { Related to production } \\
\text { and consumption }\end{array}$ & $\begin{array}{l}\text { Territorial brands, designa- } \\
\text { tions of origin }\end{array}$ \\
\hline Museum cultural district & Planned & Cultural policies & Network of museums & $\begin{array}{l}\text { Related to consumption } \\
\text { and networking }\end{array}$ & $\begin{array}{l}\text { Copyright, trademarks } \\
\text { (logos and store signs) }\end{array}$ \\
\hline $\begin{array}{l}\text { Metropolitan cultural } \\
\text { district }\end{array}$ & Planned & Urban policies & $\begin{array}{l}\text { Theatres, cinema, art } \\
\text { galleries }\end{array}$ & $\begin{array}{l}\text { Related to agglomera- } \\
\text { tion }\end{array}$ & $\begin{array}{l}\text { Copyright, authorship } \\
\text { rights }\end{array}$ \\
\hline
\end{tabular}

"culture as a process" (Throsby 2001), the author manages to mediate them providing a common background for research, i.e. the system-wide cultural district. This latter is defined as the result of a complex negotiation process among the players of the local development system and the top-down and bottom-up forces exercised by them (Sacco and Pedrini 2003; Sacco and Tavano Blessi 2006; Sacco and Ferilli 2006; Sacco et al. 2006, 2013a, b; Ferilli et al. 2016). The construction of a SWCD as a multi-level network is a complex path. It requires a stable form of government and a clear role assigned to the different nodes as to provide unity and coordination to the network (Palmi 2013). In the SWCD culture is a central component of urban regeneration interventions. Culture is essential in the identification of the cultural and natural assets to be recovered as spaces of cultural production (containers); in the management of the recovery process-both on behalf of public institutions or private developers; in the participation strategies aimed at the creation of new practices, traditions and values (contents) around the properties recovered. The SWCD's strategies on cultural heritage are mainly centred on: the quality of the cultural offer, the local governance, the production of new knowledge, the development of local firms, the attraction of foreign practitioners and companies, the participation and training of the local community, the handling of marginalization and other social problems (Sacco and Ferilli 2006; Sacco et al. 2006, 2013a, b, c; Ferilli et al. 2016).

Between 2005 and 2010 Italian literature focused inexorably on SWCD investigating it both as a "natural" and "voluntary" economic cluster, close to the classic industrial district, and as a "product" of policy-making according to the research lines outlined by Santagata and Sacco (Hinna and Seddio 2013; Palmi 2013; Ponzini et al. 2014). Meanwhile, the SWCD model has been applied in Italian regional policies, on which we will turn on later, and some ethical issues have emerged. Firstly, the political implications in the assignment of the district feasibility study to external consultants by administrators. Secondly, the attention devoted to the physical and tangible assets and to the beneficiaries of regeneration projects which has left the social and human capital owned by the district on the background (Ponzini et al. 2014; Ferilli et al. 2016, 2017; Ponzini 2016; Nuccio and Ponzini 2017). Finally, even if the idea behind the SWCD is clear, i.e. a new entrepreneurial ecosystem of the cultural and creative sector made by small and medium enterprises cross-linked to other production chains, public and private actors, financial and academic institutions at different levels and scales, in current theory and practice there is not a single, agreed definition of SWCD.

Following this first season of district policies in Italian Regions, some authors tried to shed light on the organisational and relational nature of the entrepreneurial network forming the SWCD toward a better understanding of the concept.

Ponzini (2009) studies the direct and indirect implications of cultural institutions and producers in urban revitalization and regeneration projects, regardless of their affiliation in urban regimes, recurring to the concept of cultural policy network. Arnaboldi and Spiller (2011) apply the Actor-Network Theory (ANT) rules in the construction of a cultural district in Lombardy Region. They show that the conceptualisation is facilitated by deploying three ANT rules: enrolling actors, fact-building and circulating translations. These rules can be used to define a "conditional path" whereby specific actions are activated when controversies emerge. 
According to Seddio (2013) the relational system of cultural districts is made of different operative networks characterized by a high complexity. Public, private or hybrid institutes and cultural enterprises represent the "nodes" of these networks. They collaborate inside the district in order to:

1. Widen their income within the cultural heritage chain. In this regard, it is possible to recognize networks with a mono-chain approach or a multi-chain approach;

2. Obtain a competitive advantage through integrated activities and functions. In this regard, it's possible to recognize networks based on:

a. forms of internal integration: they base on shared goals, policies, and programs (political-programmatic integration) or on a shared management in sites accessibility, public fruition, services to the public and cultural production (managerial integration);

b. forms of external integration: they base on an integrated offer of services by the network (offer integration) and on a unique image of the network itself (integration of information, promotion and communication strategies);

c. forms of multiple integration: they base on shared strategies for the harmonization of the different levels of the public system of cultural heritage thanks to the collaboration with universities and research centres (integration of the public chain) and with the other close economic chains.

For Alberti and Giusti (2009) cultural systems and museum districts present some particular features respect to other cultural networks. They have an internal hierarchy and nodes which are homogeneous for: degree of specialization, contents produced, spatial concentration and geographic relevance (regional, national, international). On this basis Usai (2016b, p. 106) defines SWCD as an international network made of enterprises and cultural institutes homogeneous for specialization and belonging to the same territory, that operate in the cultural chain and in the connected production chains, creating vertical, horizontal and transversal relations, pursuing internal, external, and multiple integration (Della Corte et al. 2018).

Despite these studies, several work is still needed to understand the nested geographies which should characterize the SWCD as an EE of the cultural and creative sector.

\section{Methodology}

The comparative research focuses on the district policies carried out by Italian regions in last 15 years as a 'testing ground. This choice comes from the following assumptions:

1. In the district model, opposite to the cluster model, the social dimension is equally important as the economic one. Not incidentally, the district model tends to prevail in the contexts with a predominance of small family-owned firms such as Italy. Here cultural districts have not developed under the planning for the arts but thanks to the application of Becattini's industrial district idea to cultural heritage management (Sacco et al. 2013a; Usai 2016a, b). Thus, Italian SWCD can be analysed and studied under the main framework of EE, an entrepreneurial model which lays in the innovation literature regarding SMEs.

2. In Italy there are different kinds of cultural-based development policies and of cultural networks, as highlighted by Seddio (2013) and Alberti and Giusti (2009). However, to investigate the SWCD's nested geography as an EE, it seems more interesting to concentrate on those networks that the policy makers themselves have called "cultural district" in order to understand if they are really SWCDs or, on the contrary, if they are cultural networks of other kind. For this reason, we focus on cultural networks having the key words "cultural district" or "district" in the name, in the administrative acts of constitution and in the institutional communication channels.

3. Systematic studies and abundant evidences confirm that the leading contribution of authors like Valentino, Santagata and Sacco between 2000 and 2015 has influenced, directly or indirectly, the policy production in Italy by regional governments in the cultural and creative field (Ponzini et al. 2014; Montella 2015; Ponzini 2016; Usai 2016a, b; Nuccio and Ponzini 2017). Therefore, it is not to be excluded that cultural districts born in this period thanks to public policies, should embody at least some characteristics of a SWCD. For this reason, they represent an ideal sample to explore SWCD's internal structure and we decide to focus on them in the study.

The methodological framework adopted in the study is illustrated in Table 2. It relies on:

- The concept of EE developed by Brown and Mason (2017). We use it studying cultural districts and SWCDs as entrepreneurial ecosystems of the cultural and creative sector; 


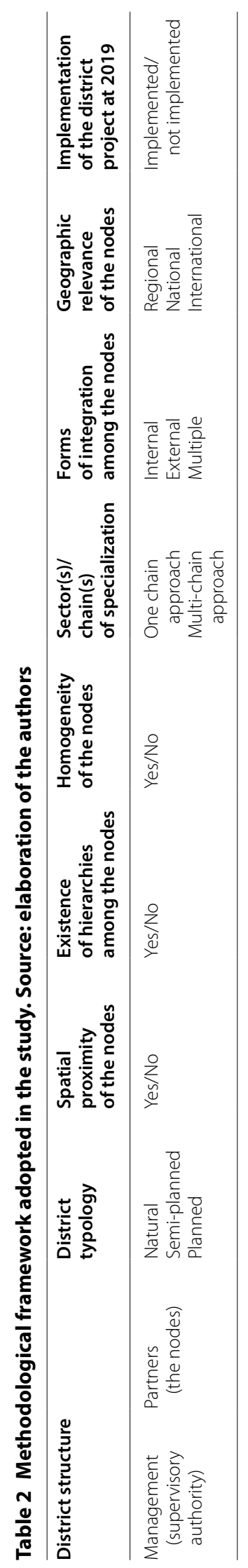


- The distinction among natural, planned and semiplanned cultural districts adopted in Santagata (2002) and Hinna and Seddio (2013);

- The one-chain and multi-chain approaches as well as the different form of integration (internal, external and multiple) outlined by Seddio (2013) for the SWCD;

- The features of cultural and museum districts illustrated by Alberti and Giusti (2009): spatial proximity of the district management and nodes; existence of internal hierarchy, homogeneity of the nodes (specialization, spatial concentration), geographic relevance (regional, national, international).

- The definition of SWCD in Usai (2016b, p. 106).

We use this framework to map and compare the cultural districts operating from 2000 to 2015 in Italian administrative regions, coinciding also with statistical NUTS-2 regions. We start from an analysis of the national urban policies which support the construction of cultural districts in Italian administrative regions, the broader context of our research. Later we analyse the internal structure of each district on the base of the legal and administrative acts of constitution and the institutional communication channels (publications, website, etc.). In particular, we consider the following factors:

- The link with public policies on culture and creativity (which policies/initiatives supported the district creation);

- The organizational features: subjects that are part of the district according to the Statute (territory in which they settle, links with the other subjects of the district, sector/chain of specialization; local/national/ international relevance of projects and partners).

- The links with the urban and landscape planning related to cultural heritage;

- The state of art today (implementation or not of the district project at 2019).

\section{The research context: national urban policies supporting the construction of cultural districts by Italian Regions}

Starting from the 2000s, the birth of new production chains connected to urban renewal and to the valorisation of cultural heritage, in spite of the crisis of traditional industry, pushed public administrations to engage in creative spatial policies. Local administrators tried to quantify the cultural field and its added value ${ }^{3}$ (see Table 3).

\footnotetext{
${ }^{3}$ See Centro Studi Touring Club Italiano, Indagine sulla consistenza del patrimonio culturale immobile di interesse turistico, July 2003 (survey conducted for the Ministry of Culture).
}

In 2001 the reform of Title $\mathrm{V}$ of the Constitution redefined the responsibilities by the State and the first-level administrative regions, hereafter the Regions, with respect to the cultural heritage. Heritage protection was assigned to the former while heritage valorisation to the latter. Heritage valorisation and cultural services, already subject to the regulations on public works, became a complex matter requiring new operational tools. Between 2000 and 2003, several normative interventions tried to handle the question comparing it to the managerial issue posed by the programs for infrastructures and urban renewal. However, the policies of national government, mainly aimed at the privatization and alienation of the public historical properties, were fruitless. In this period, even the production of reports on cultural economy stopped (Ponzini 2008; Colavitti and Usai 2014; Usai 2016a, b).

In 2004, the Italian Code on cultural heritage and landscape (L.D.42/2004) introduces further forms of valorisation to renovate the policy making for culture and its governance. ${ }^{4}$ Several studies on the cultural and creative economy are published (see Table 3). The most relevant is the white paper on Creativity edited by the Commission of creativity and culture production in Italy of the Ministry of Culture, chaired by Walter Santagata. The white paper has the merit to apply the chain analysis to cultural and creative economy in Italy, to identify strategic policy-actions in the field of architecture and, above all, to establish a fund for the creative capital, supported by the Ministry of Culture, by the Ministry for Economy, by the Ministry of Youth, and by the largest banks of the country (Action 70). In 2010 the fund supported the research project Italia Creativa which involved the association Giovani Artisti Italiani (GAI, Young Italian Artists) and the Ministry for Youth.

Between 2010 and 2015 the economic crisis imposes a limit to public expenditure and accelerates the diffusion of market-oriented management and project financing in the field of culture. Italian cities are asked to rationalize the spending and maximize their results concentrating on a small number of strategic interventions. Public-private partnerships are encouraged in the dispossession of State properties as well as in the National Plan for the Cities of 2011. New tools for cultural planning and heritage management are created: the Piani strategici di valorizzazione e sviluppo culturale (PUVAT, Strategic plans of valorisation and cultural development), the Contratto di Valorizzazione Urbana (CdV, Contract of

\footnotetext{
${ }^{4}$ On the topic, see Colavitti and Usai (2014), Colavitti (2018), Colavitti et al. (2018).
} 
Table 3 Italian statistics on cultural and creative industries between 2000 and 2015. Source: elaboration of the authors

\begin{tabular}{|c|c|c|}
\hline Year & Report/indicator & References \\
\hline $2000-2005$ & Report on the economy of culture in Italy 1990-2000 & Bodo and Spada (2004) \\
\hline \multirow[t]{8}{*}{$2005-2010$} & Italian Creativity Index & Florida and Tinagli (2005) \\
\hline & Report "La città dei creativi" & ANCE (2005) \\
\hline & Cultural Profitability Index & Santagata (2007) \\
\hline & Report "Le attività economiche collegate alla valorizzazione del patrimonio culturale" & MiBAC e Istituto Tagliacarne (2007) \\
\hline & Statistical classification of the economic activities: Ateco 2007 built on NACE Rev. 2 & ISTAT (2009) \\
\hline & Report "Il sistema economico integrato dei beni culturali" & Unioncamere and Istituto Tagliacarne (2009) \\
\hline & 4T's Model & Carta (2009) \\
\hline & White Paper on Creativity & $\operatorname{MiBAC}(2009)$ \\
\hline \multirow[t]{6}{*}{$2010-2015$} & GAl, Italian Creativity Index & Cicerchia $(2010,2013)$ \\
\hline & Report "La valutazione sulla creatività nelle regioni italiane" & Pini and Rinaldi (2010) \\
\hline & Report "L'Italia che verrà. Industria culturale, made in Italy e territori" & Unioncamere and Symbola $(2011,2012,2013,2014)$ \\
\hline & IX Report of Federculture "Una strategia per la cultura, una strategia per il paese" & Grossi (2013) \\
\hline & Book "La nuova occasione. Città e valorizzazione delle risorse locali" & Casavola and Trigilia (2013) \\
\hline & BES Report & ISTAT $(2013,2014)$ \\
\hline
\end{tabular}

Urban Valorization). ${ }^{5}$ The clustering of cultural and creative actors is supported through the European funds, ${ }^{6}$ the National Guarantee Fund for small and medium businesses as well as the National Plan for the Cities. ${ }^{7}$ Moreover, all actions founded can be refinanced with the cycle of programming 2014-2020. A great support to policy making is also offered by empirical studies which investigate the connection between territory and cultural systems, the advantages and the problems coming from this link, above all in cities (see Table 3).

The joint initiatives of the Ministry of Culture and the Ministry for Territorial Cohesion, like the Cultura in movimento project (Moving culture) and the Expo 2015 nelle Regioni project, and the programs on technological districts

\footnotetext{
${ }^{5}$ On this topic, see Usai (2016a, b), Colavitti and Usai (2014), Colavitti (2018), Colavitti et al. (2018).

${ }^{6}$ Even if the delay in the spending of resources coming from the 2007-2013 Structural Funds and from the 2007-2013 Fund for Development and Cohesion, above all in the South of Italy, required three interventions of redistribution by the central government. The first intervention coincided with the National Action Plan for Cohesion (APC) of May 2012, wanted by the then Ministry for Development and Cohesion, Fabrizio Barca. Thanks to this plan, 330 million Euros for the protection and valorisation of national cultural assets have been reassigned. The second intervention, dated June 2013, consisted in the reduction of national cofounding of the National Operative Program (NOP) of the Convergence Objective for 1 billion Euros. These resources, integrated with funding from the national APC, have been destined to measures for youth employment and against poverty. To accelerate the expense, they instituted special units at the Department for development and cohesion. The third reassignment, which took place in December 2013, supported several initiatives dedicated to the development of the local economy and to projects for employment and the war against poverty.

7 For interventions included in the Regional Operative Programs (ROPs) and with the closing of the works within December 2015.
}

and clusters ${ }^{8}$ by the Ministry of University and Research (MIUR) work in this direction. They express the desire to accelerate the spending of national and European funds in the attempt to build adequate policies for culture and creativity (Sacco 2011; Kern and Montalto 2013; Trigilia 2014).

\section{The organisational models adopted by cultural districts in Italian Regions: a comparative analysis}

Since 2000, the Italian Regions, i.e. the first-level administrative regions-whose territory coincides also with NUTS-2 statistical regions-have showed an increasing interest towards the economies deriving from the valorisation of culture. Despite this, the framework of regional policies for cultural districts in 2015 is still fragmented with (see Table 4):

1. Regions without regional laws on cultural districts and without cultural districts;

2. Regions without regional law on cultural districts where some cultural districts are operating because of the program on technological districts by the Ministry of Education-MIUR, programs by the Provinces and Municipalities or private initiatives;

3. Regions with laws on industrial districts, including the cultural ones, where some cultural districts are operating;

4. Regions with laws on cultural districts but without cultural districts;

5. Regions with laws on cultural districts where some cultural districts are operating.

\footnotetext{
${ }^{8}$ National Operative Programs on innovation and research for 2005-2007, 2007-2013 and 2014-2020.
} 
Table 4 Regional policies for cultural districts (CDs) and cultural districts operating in Italian regions. Source: elaboration of the authors on Ponzini et al. (2014), Nuccio and Ponzini (2017), Usai (2016a, b)

\begin{tabular}{|c|c|c|}
\hline State of art of regional policies & NUT2-regions & Cultural districts operating in the region \\
\hline \multirow[t]{3}{*}{ No regional law on CDs and no operational cultural districts } & Emilia Romagna & $\begin{array}{l}\text { Even if cultural networks are present and ruled by mean of } \\
\text { network contracts }\end{array}$ \\
\hline & Valle d'Aosta & - \\
\hline & Umbria & - \\
\hline \multirow{4}{*}{$\begin{array}{l}\text { No regional law on CDs but some are operating because of the } \\
\text { Program on technological districts by the Ministry of Educa- } \\
\text { tion - MIUR. }\end{array}$} & Calabria & Distretto Tecnologico dei Beni Culturali di Crotone in Calabria \\
\hline & Campania & $\begin{array}{l}\text { Distretto ad Alta Tecnologia per i Beni Culturali (DATABENC) in } \\
\text { Campania }\end{array}$ \\
\hline & Lazio & Distretto Tecnologico per i Beni Culturali del Lazio \\
\hline & Tuscany & $\begin{array}{l}\text { Distretto per le tecnologie dei beni culturali e della città sosteni- } \\
\text { bile (DiT-BeCs) }\end{array}$ \\
\hline \multirow{4}{*}{$\begin{array}{l}\text { No regional law on CDs but some are operating because of } \\
\text { Provinces and Municipalities }\end{array}$} & Liguria & Distretto culturale della Provincia di Isernia \\
\hline & Molise & Distretto delle Terre Pentre \\
\hline & Piedmont & Distretto delle Langhe e del Monferrato \\
\hline & Trentino Alto Adige & Distretto culturale Rovereto Trento \\
\hline $\begin{array}{l}\text { No regional law on CDs but some are operating because of } \\
\text { private initiatives }\end{array}$ & Lombardy & $\begin{array}{l}\text { Distretto Culturale della Valle Camonica } \\
\text { Distretto Dominus. Oltrepo'Mantovano } \\
\text { Distretto Le Regge dei Gonzaga } \\
\text { Distretto Culturale di Monza e Brianza } \\
\text { Distretto Culturale della Provincia di Cremona } \\
\text { Distretto Culturale della Valtellina }\end{array}$ \\
\hline \multirow{3}{*}{$\begin{array}{l}\text { Regional law on industrial districts, which includes CDs, and } \\
\text { some are operating }\end{array}$} & Apulia & Distretto Puglia Creativa \\
\hline & Sicily & Distretto Culturale del Sud Est \\
\hline & Veneto & $\begin{array}{l}\text { Distretto Produttivo Turistico Culturale delle Province di Venezia, } \\
\text { Rovigo, Treviso e Vicenza } \\
\text { Meta-distretto Veneto dei Beni Culturali e Ambientali }\end{array}$ \\
\hline Regional law on CDs but none is operating & $\begin{array}{l}\text { Abruzzo, Friuli } \\
\text { Venezia Giulia, } \\
\text { Sardinia }\end{array}$ & - \\
\hline Regional law on CDs and some are operating & Marche & $\begin{array}{l}\text { Distretto Culturale della Provincia di Ascoli Piceno } \\
\text { Distretto Culturale di Urbino e Montefeltro } \\
\text { Distretto Culturale Evoluto delle Marche }\end{array}$ \\
\hline
\end{tabular}

The districts set up at regional level are 20: the first place goes to Lombardy with six districts, followed by Marche with three and by Veneto with two. The Regions that took part in the call on technological districts by MIUR (National program of Research 2005-2007) host a technological district each.

The distribution of the districts in relation to the creation mechanisms is homogeneous with four districts born thanks to the MIUR's calls, four thanks to the regional laws on industrial districts and three thanks to the regional laws on cultural districts (see Tables 5, 6, 7, 8 and 9). The legislative intervention by Regions does not represent a decisive element since ten cultural districts have been created in the regions without a specific discipline (six in Lombardy, one in Molise, one in Piedmont, one in Trentino Alto Adige). The adoption of regional laws for districts often depends on the presence of a 3-year work program with a clear strategy behind it, as in Friuli Venezia Giulia, Sardinia and Marche regions. However, Friuli Venezia Giulia, Sardinia and Abruzzo regions confirm that the laws do not always lead to operating districts due to political implications, which in the case of cultural heritage, seem to be perceived as an "uncomfortable fact" by scholars and administrators. Especially in the assignment of the district feasibility study to external consultants (Ponzini et al. 2014). In this sense, Marche region represents an exception with two pre-existing districts (created by local administrations) that have been strengthened by the regional law on cultural districts, and one regional district under construction using the same law.

Considering the framework we propose (Table 2), the national systems of cultural districts is actually composed of the following relational and organizational networks: technological districts, a meta-district for restoration and preservation, districts for cultural tourism, districts for wine and food, traditional cultural districts, and museum districts (see Tables 5, 6, 7, 8 and 9). Generally these latter are simple cultural networks or local cultural system. They are the result of the old regional policies for culture 


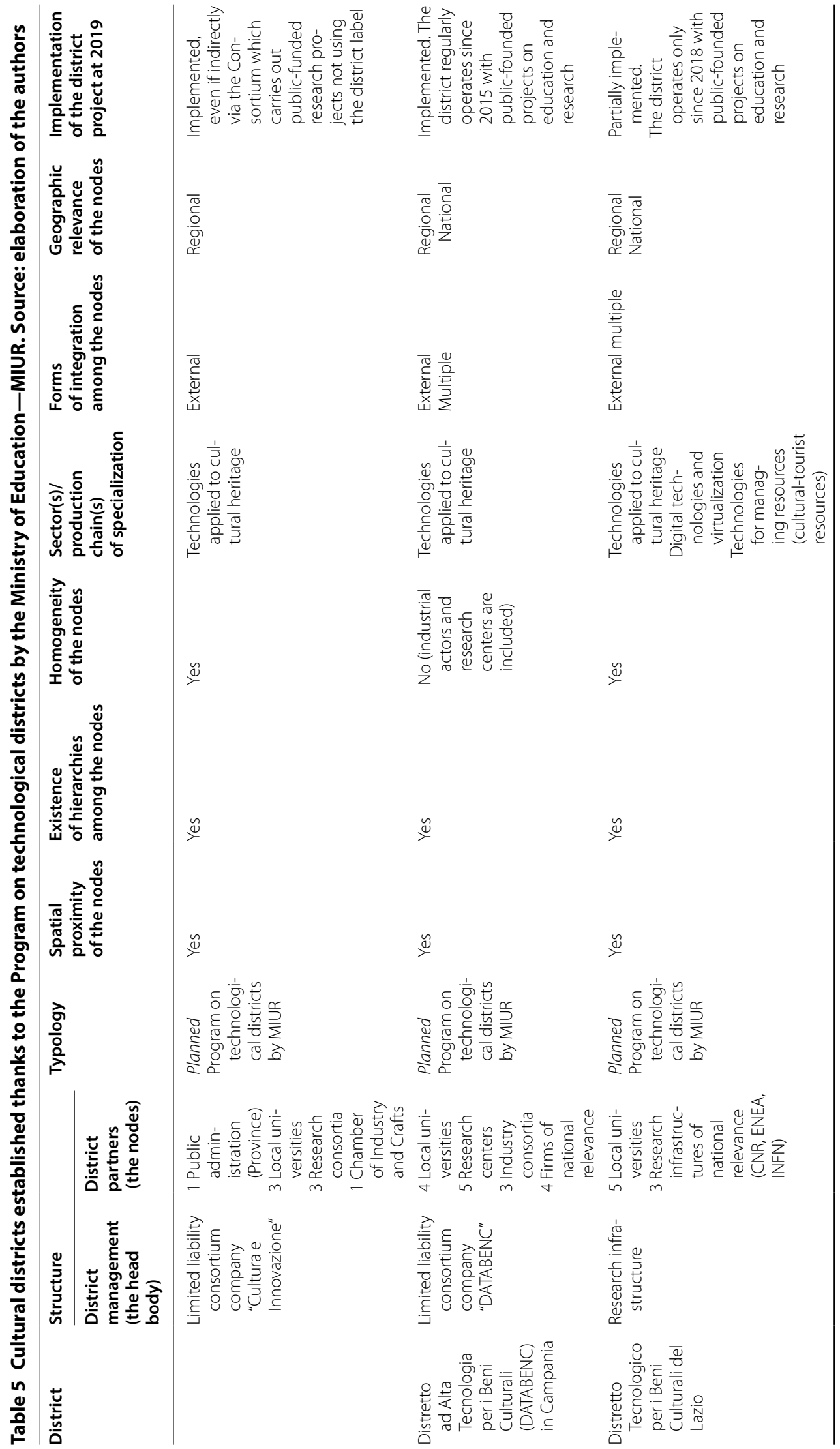




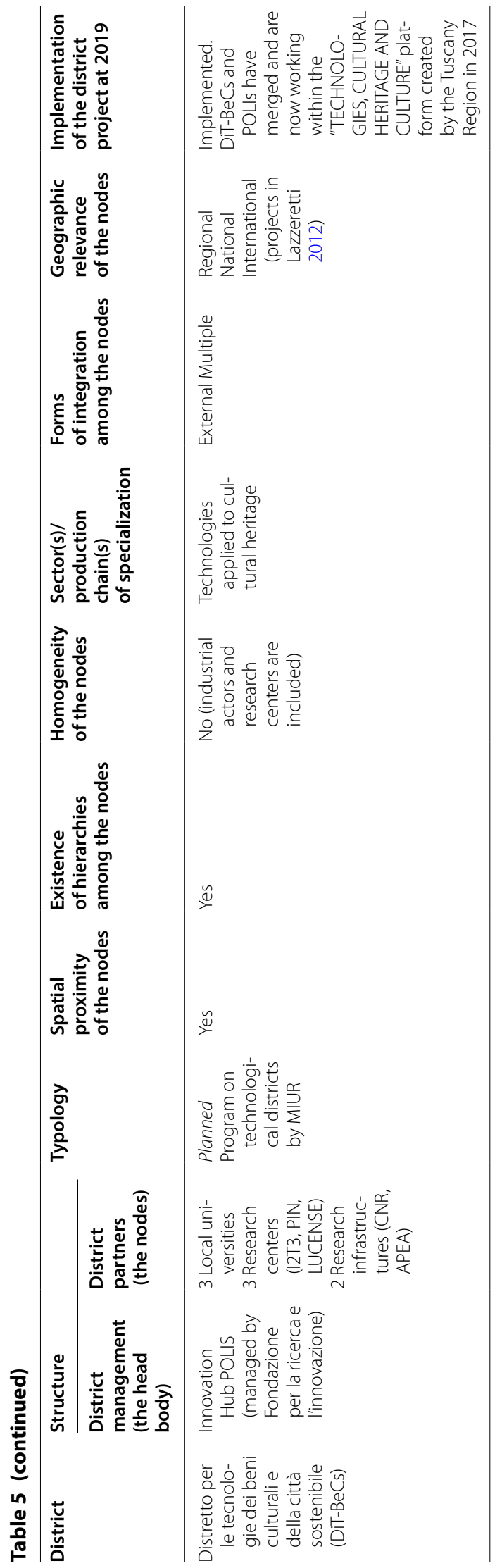




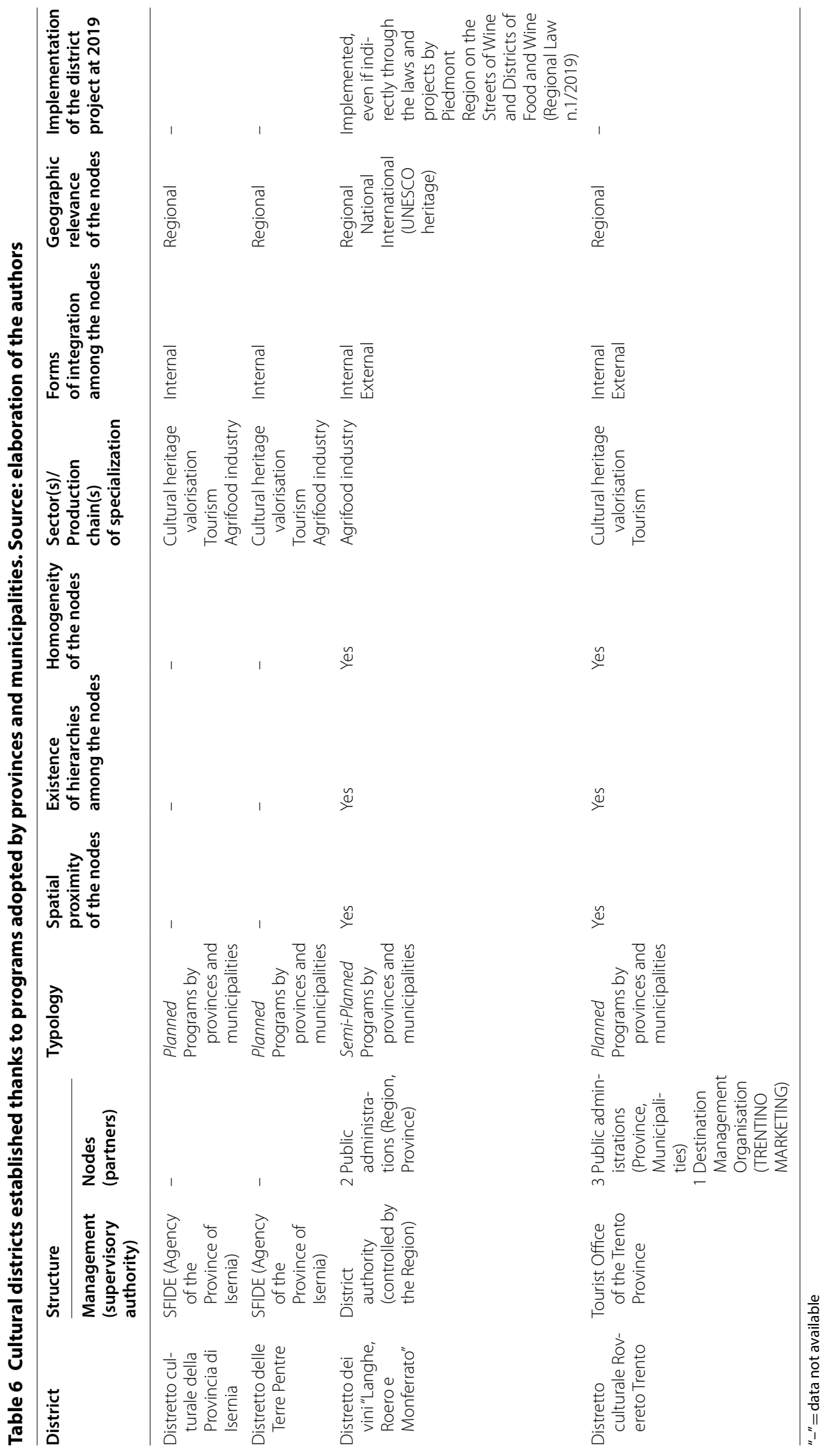




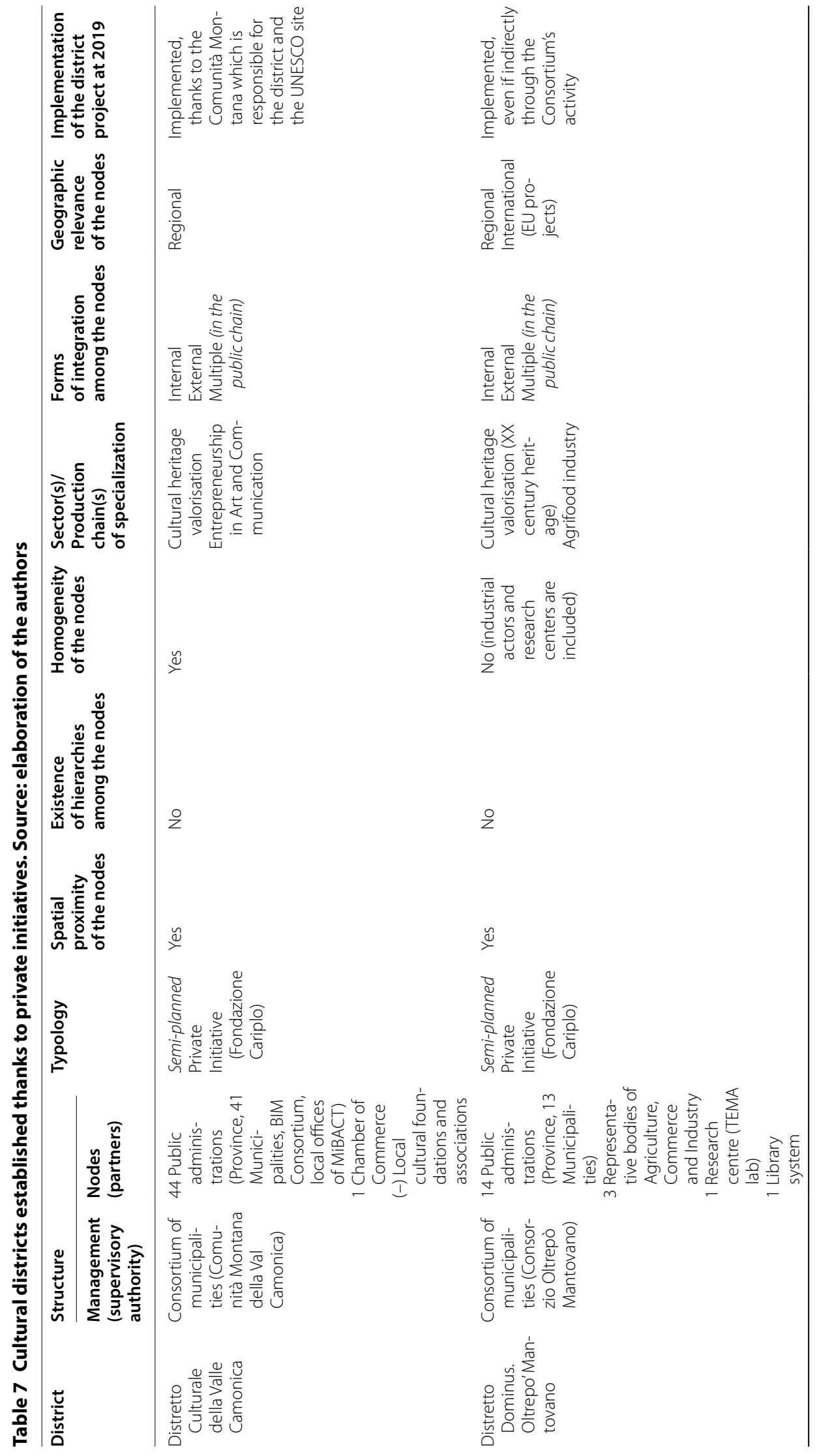




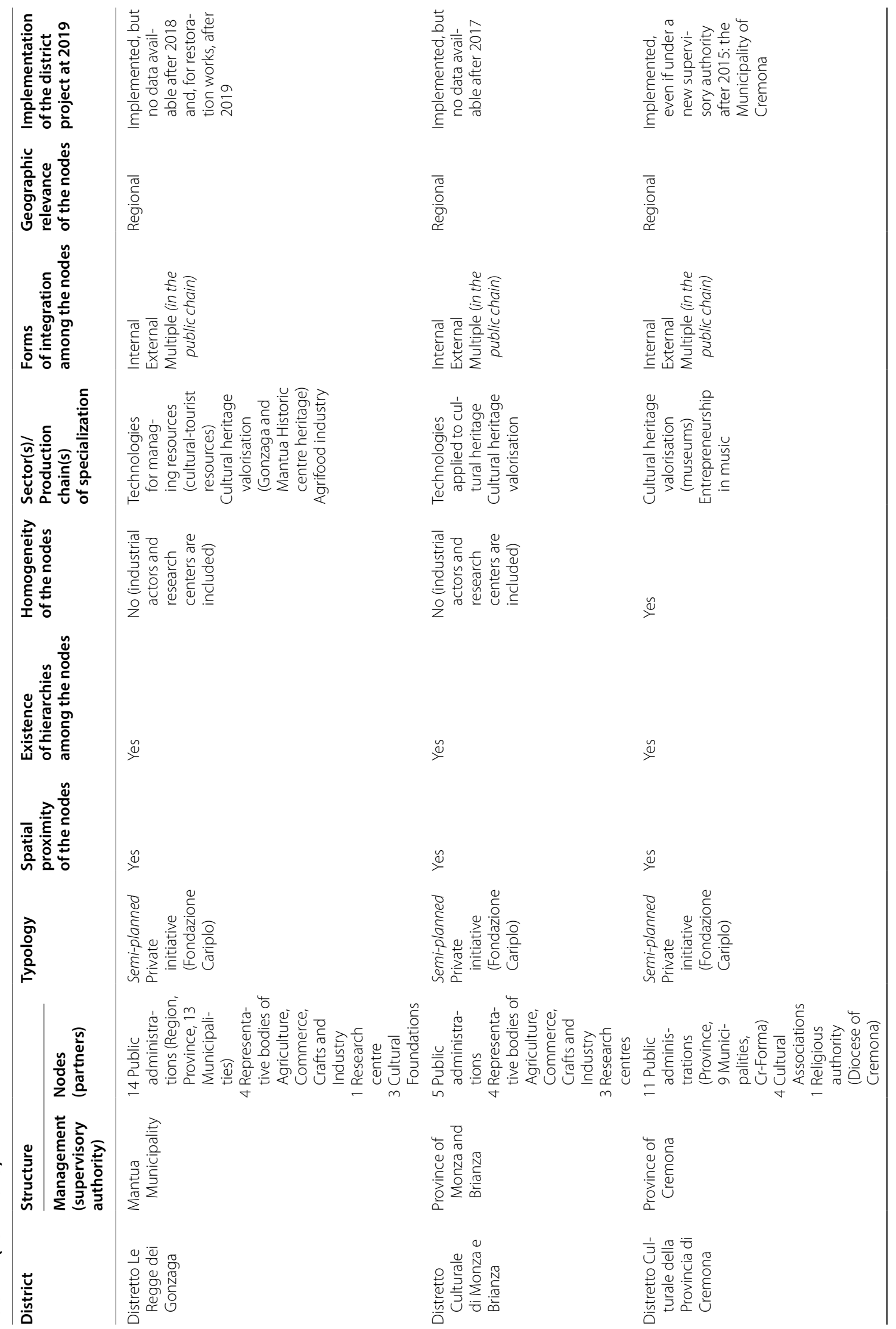




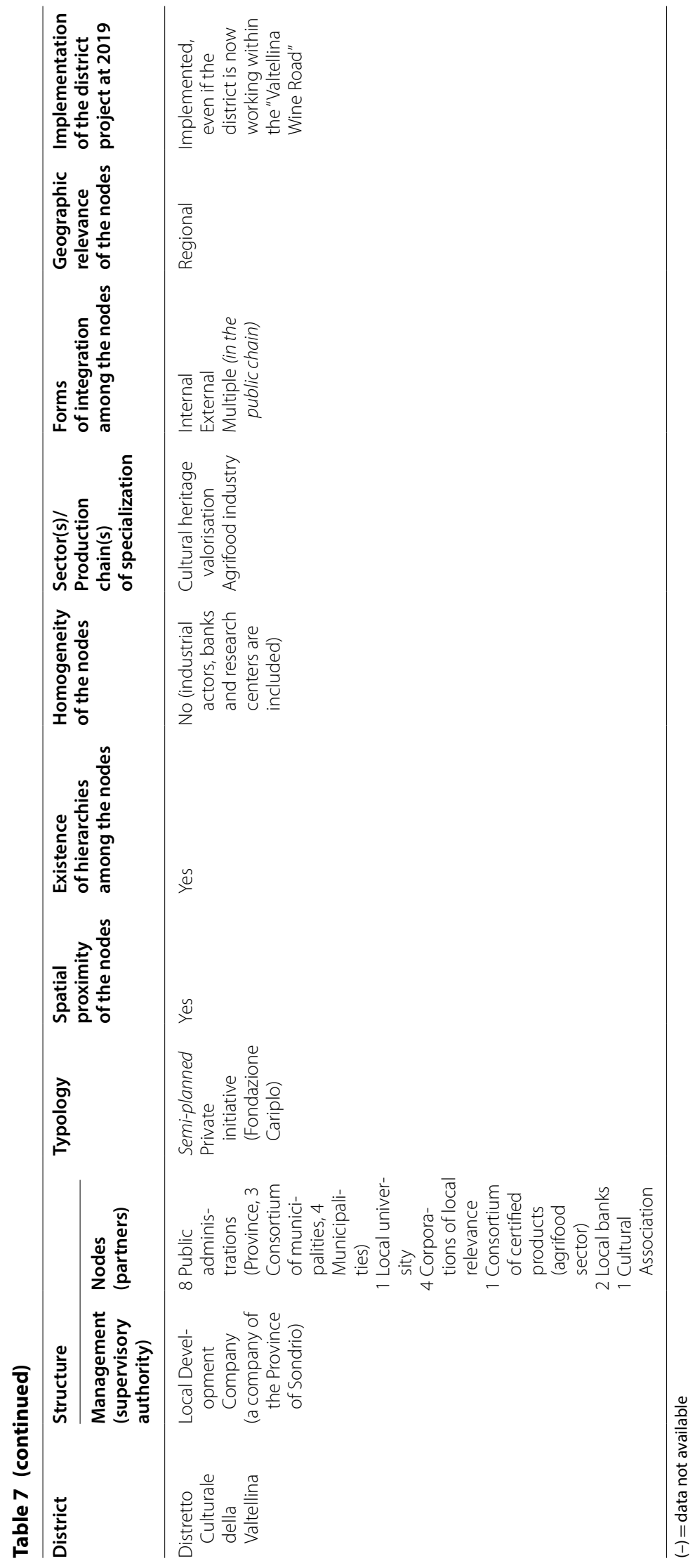




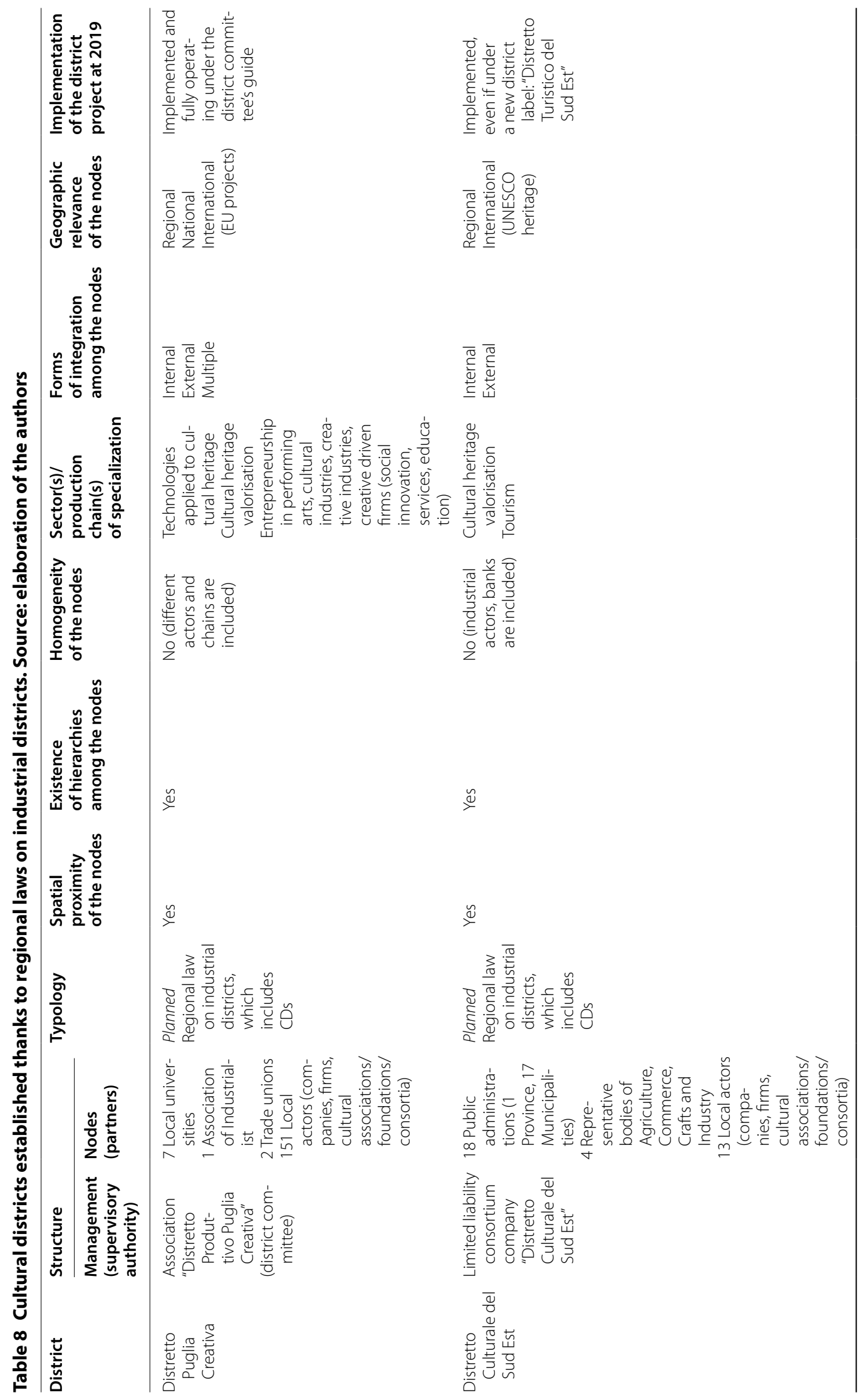




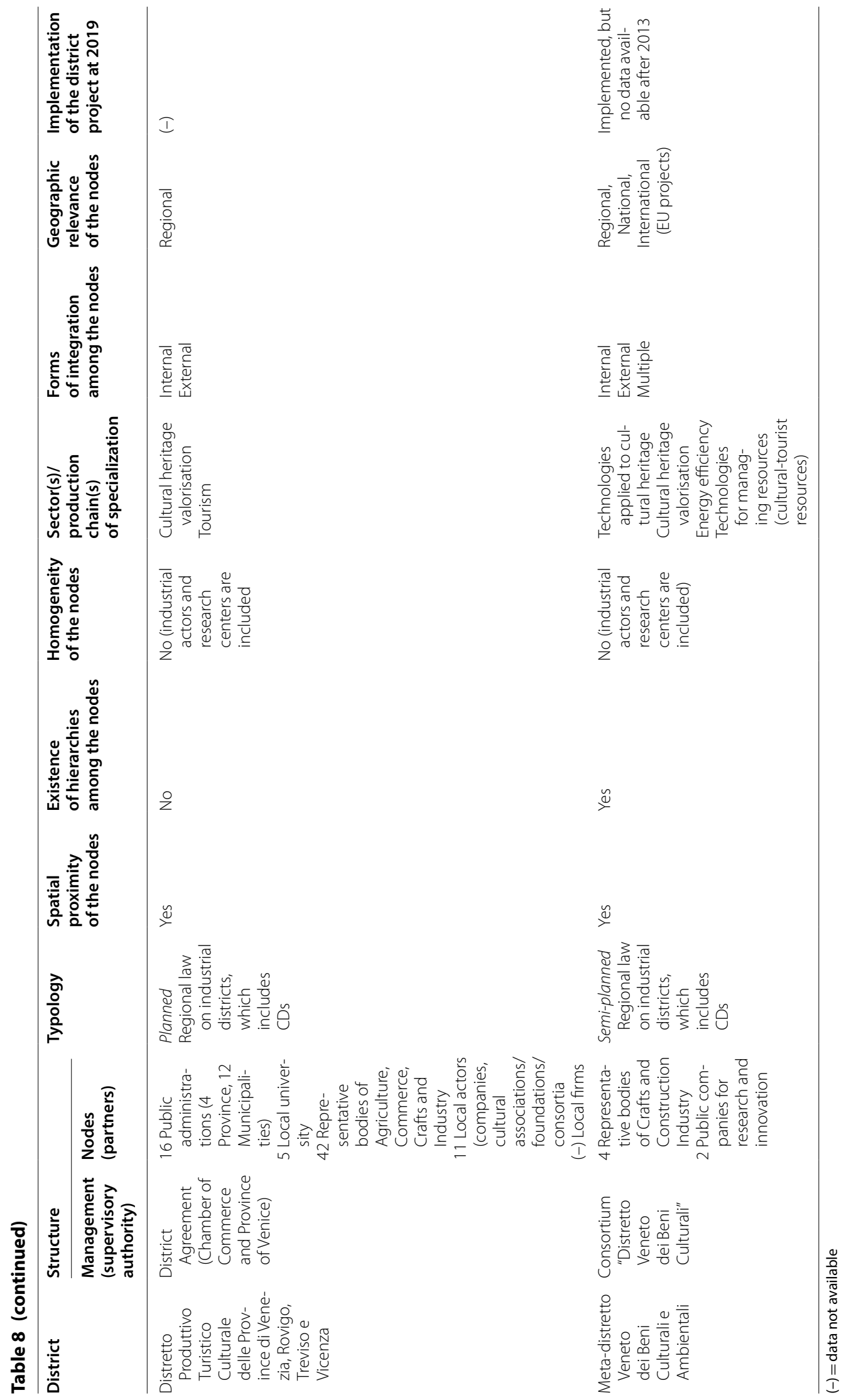




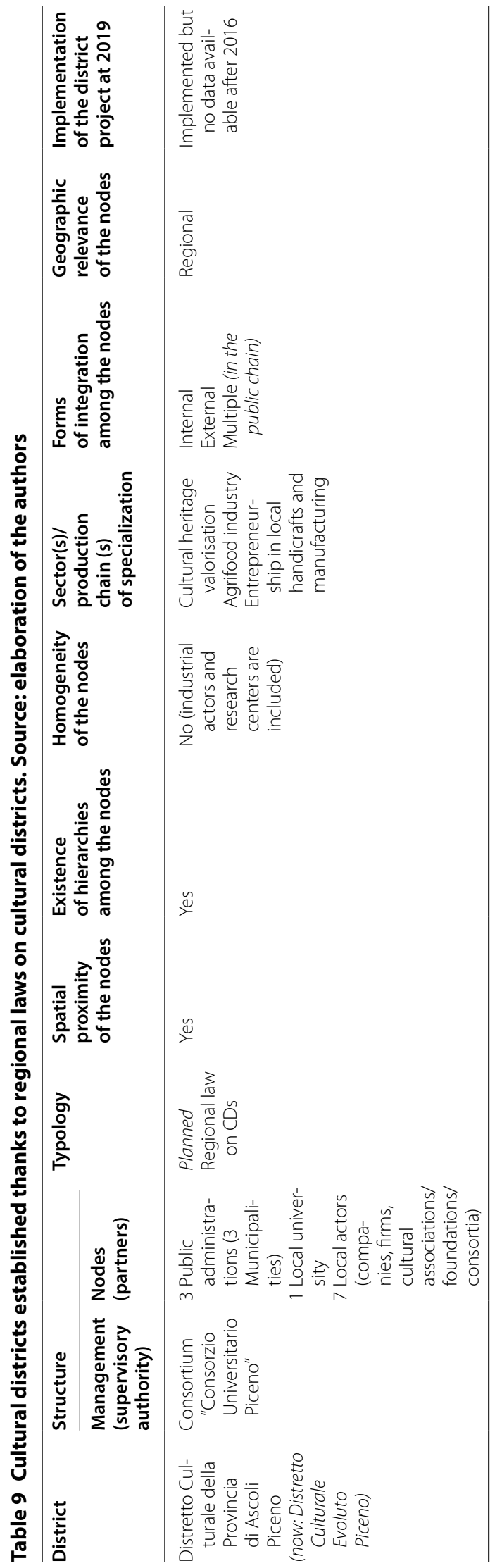




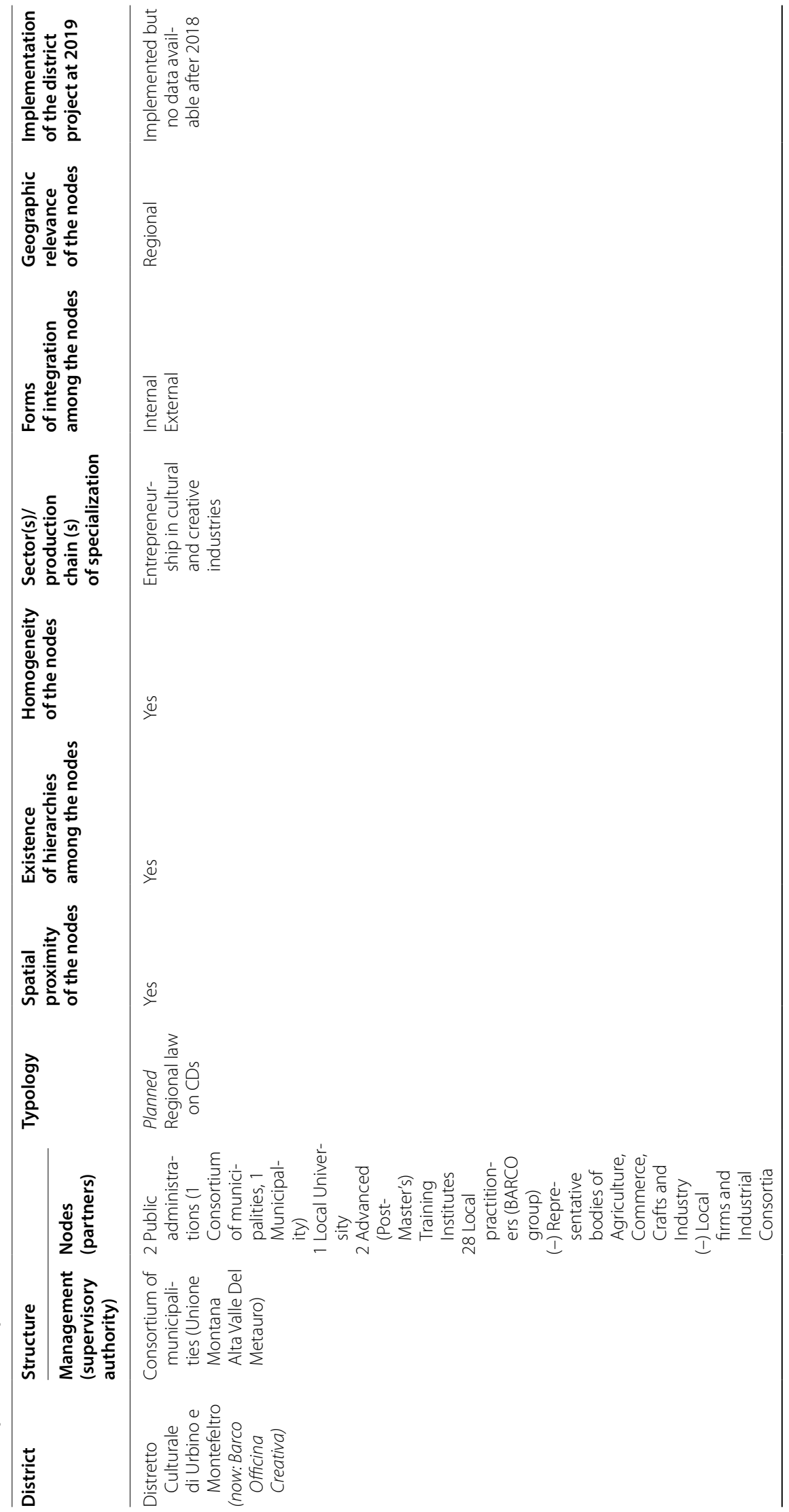




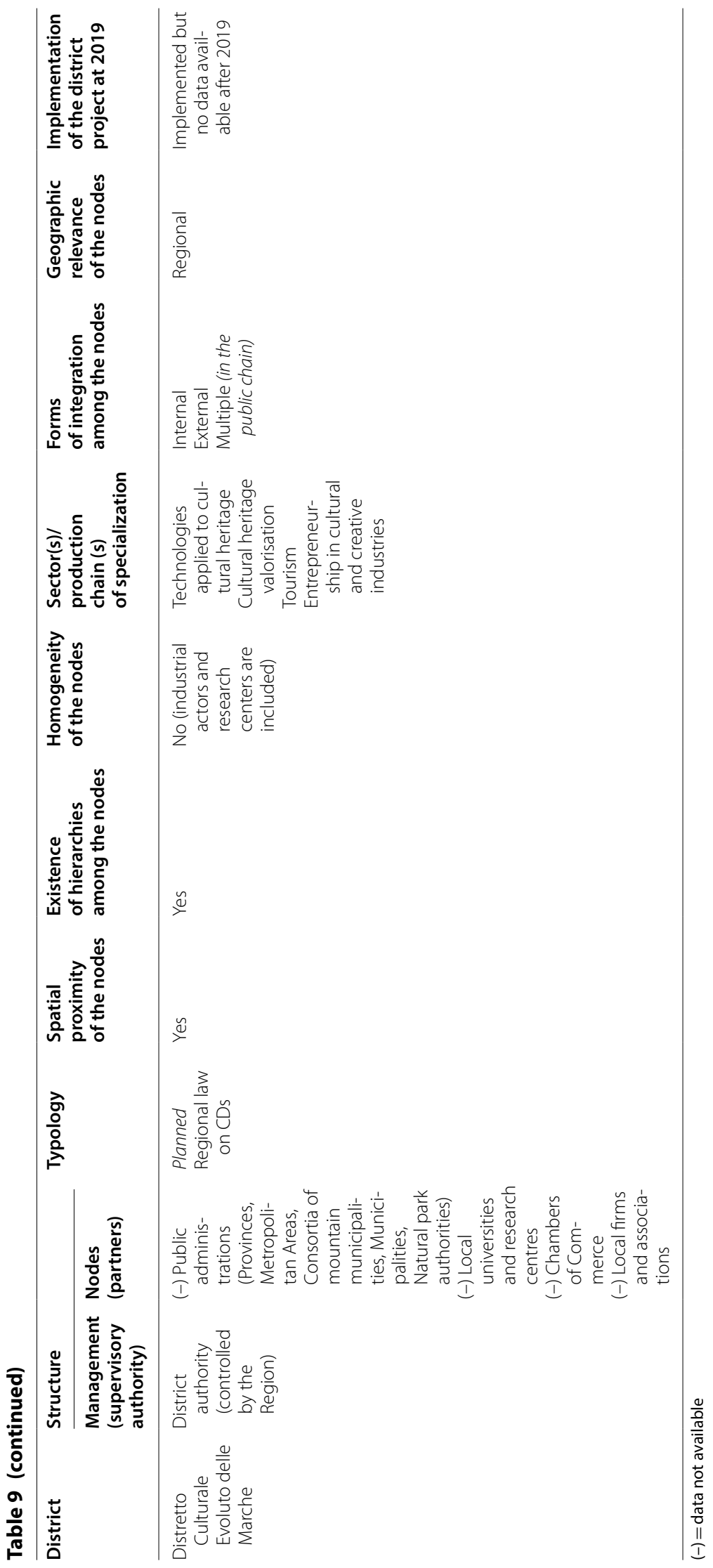


or, instead, the outcome of some recent projects on cultural/tourist districts that were not able to evolve remaining at a rudimentary stage, as for the Distretto Culturale del Sud-Est (Cultural District of the South-East) in Sicily (Carta 2003).

In the national landscape, only the DiT-BeCs and Puglia Creativa districts in Tuscany and Puglia can be defined SWCDs, while, the cultural districts funded by Fondazione Cariplo in Lombardy and, recently, by the Marche Region cannot be defined as such due to a multiple integration that mainly concern the public domain (Montella 2015; Ponzini 2016; Usai 2016a, b; Nuccio and Ponzini 2017).

Considering the urban policies, the places of culture (i.e. museums, research centres, archives, etc.) are often the focus of cultural districts' activities. Thus, local urban strategies and major projects are taken in great consideration by the district boards in the projects of recovery for heritage assets and landscapes. ${ }^{9}$ This is the case of the Regge dei Gonzaga, the Barco Ducale of Urbania and the Polironiano Complex in San Benedetto Po in the cultural districts of Lombardy financed by Fondazione Cariplo (Barbetta et al. 2013; Camerlengo 2013). Nonetheless, among all the Regional Landscape Plans ${ }^{10}$ only those adopted by Campania Region took care of the construction of cultural districts (even though according to a tourist approach).

\section{Result discussion and conclusions}

In spite of a relevant theoretical contribution to the international debate and an almost continuous statistical production on the field, the analysis of the national context evidence a remarkable delay in public policies supporting culture and creativity and in their governance. It is enough to think that cultural and creative sector is still exclusively the responsibility of the Ministry of Culture, even though national programs frequently require the involvement of different Ministries, e.g. in the National Plan for the Cities (Ministry of Culture and Ministry of Infrastructure and Transport) and in the Italia Creativa project (Ministry of Culture and Ministry for Youth). Moreover, the support to cultural and creative industries at national level relies completely on the programs for technological districts and clusters of the MIUR, a part

\footnotetext{
${ }^{9}$ The reference here is to landscape planning as defined by the European Convention of Landscape: "Landscape planning" means strong forward-looking action to enhance, restore or create landscapes" (Council of Europe 2000, art.1 letter e).

10 Plans of regional level for the protection and valorisation of cultural heritage and landscapes through a sustainable land-use (L.D.42/2004). They overarch the urban planning tools adopted by cities and towns, so as to resolve the historical conflict between urban planning and safeguard of the cultural heritage, born with the 1942 Town and Country Planning Act.
}

for a few thematic projects adopted by other Ministries (Valore Cultura, EXPO 2015 per le Regioni and, again, Italia Creativa).

The absence of a clear and transparent policy framework for culture and creativity at national level, is compensated for some extent by the regional policies which have favoured the insurgence of cultural districts on the whole national territory (Montella 2015; Ponzini 2016; Usai 2016a, b; Nuccio and Ponzini 2017).

In this regard, our analysis of regional policies shows how cultural districts weave with other forms of district, as in the case of the districts for food and wine (Piedmont), tourist districts (Campania, Molise, Sicily, and Trentino) or technological districts for restoration and preservation (Tuscany). It confirms also the existence of cultural networks with relational and organizational features that are not present in the frameworks designed by Santagata (2002) and Sacco et al. (2006, 2013a, b, c) for cultural districts. Thanks to the framework we adopt, they have been identified more clearly and classified into (see Table 10).

\section{Cultural network}

A network of regional relevance made by enterprises and cultural institutions which operate within one or more production chains, according to the nodes' specialisation, pursuing an internal integration. The following networks respond to the cultural network model: Distretto culturale della Provincia di Isernia, Distretto delle Terre Pentre, Distretto Culturale del Sud Est, Distretto Produttivo Turistico Culturale delle Province di Venezia, Rovigo, Treviso e Vicenza.

\section{(Local) cultural system}

A network of regional relevance made by enterprises and cultural institutions belonging to the same territory and homogeneous for specialization, that operate in the cultural heritage chain or in another production chain creating hierarchical and horizontal relations, pursuing an internal and external integration. The following networks respond to the (local) cultural system model: Distretto dei vini "Langhe, Roero e Monferrato", Distretto culturale Rovereto Trento, Distretto Culturale di Urbino e Montefeltro.

\section{Technological cluster}

A network of regional and national relevance constituted by enterprises and cultural institutions belonging to the same territory, homogeneous for specialization, that operate within the cultural heritage chain, or in its phases, creating horizontal and hierarchic relation and pursuing external and multiple integration. The following networks respond to the technological cluster model: 
Table 10 Cultural networks working under the umbrella concept of cultural district: a classification based on the relational and organisational features. Source: elaboration of the authors

\begin{tabular}{|c|c|c|c|c|c|c|}
\hline Type of network & $\begin{array}{l}\text { Spatial } \\
\text { proximity } \\
\text { of the nodes }\end{array}$ & $\begin{array}{l}\text { Existence } \\
\text { of hierarchies }\end{array}$ & $\begin{array}{l}\text { Homogeneity } \\
\text { of the nodes }\end{array}$ & $\begin{array}{l}\text { Approach } \\
\text { in production }\end{array}$ & $\begin{array}{l}\text { Forms } \\
\text { of integration }\end{array}$ & $\begin{array}{l}\text { Geographic } \\
\text { relevance }\end{array}$ \\
\hline Cultural network & Yes & $\begin{array}{l}\text { Yes/no (according to } \\
\text { the nodes'speciali- } \\
\text { sation) }\end{array}$ & $\begin{array}{l}\text { Yes/no (according to } \\
\text { the nodes'speciali- } \\
\text { sation) }\end{array}$ & $\begin{array}{l}\text { One or more } \\
\text { production chains } \\
\text { (according to the } \\
\text { nodes'specialisa- } \\
\text { tion) }\end{array}$ & Internal & Regional \\
\hline $\begin{array}{l}\text { (Local) cultural } \\
\text { system }\end{array}$ & Yes & Yes & Yes & $\begin{array}{l}\text { One production } \\
\text { chain (cultural } \\
\text { heritage or another } \\
\text { production chain) }\end{array}$ & $\begin{array}{l}\text { Internal } \\
\text { External }\end{array}$ & Regional \\
\hline Technological Cluster & Yes & Yes & Yes & $\begin{array}{l}\text { One production } \\
\text { chain (only some } \\
\text { phases of the } \\
\text { cultural heritage } \\
\text { chain) }\end{array}$ & $\begin{array}{l}\text { External } \\
\text { Multiple }\end{array}$ & $\begin{array}{l}\text { Regional } \\
\text { National }\end{array}$ \\
\hline Cultural district & Yes & Yes & $\begin{array}{l}\text { Yes/no (according to } \\
\text { the nodes'speciali- } \\
\text { sation) }\end{array}$ & $\begin{array}{l}\text { Plurality of produc- } \\
\text { tion chains } \\
\text { (cultural heritage } \\
\text { chain }+ \text { a relate } \\
\text { production chain } \\
\text { like agrifood, tour- } \\
\text { ism,...) }\end{array}$ & $\begin{array}{l}\text { Internal } \\
\text { External } \\
\text { Multiple (harmoniza- } \\
\text { tion of the public } \\
\text { sector) }\end{array}$ & Regional \\
\hline $\begin{array}{l}\text { System-wide cultural } \\
\text { district }\end{array}$ & Yes & Yes & No & $\begin{array}{l}\text { Plurality of produc- } \\
\text { tion chains }\end{array}$ & $\begin{array}{l}\text { Internal } \\
\text { External } \\
\text { Multiple }\end{array}$ & $\begin{array}{l}\text { Regional } \\
\text { National } \\
\text { International }\end{array}$ \\
\hline Meta-district & $\begin{array}{l}\text { Yes/no (exten- } \\
\text { sive use of } \\
\text { ICT) }\end{array}$ & Yes & No & $\begin{array}{l}\text { Plurality of produc- } \\
\text { tion chains }\end{array}$ & $\begin{array}{l}\text { Internal } \\
\text { External } \\
\text { Multiple }\end{array}$ & $\begin{array}{l}\text { Regional National } \\
\text { International }\end{array}$ \\
\hline
\end{tabular}

Distretto Tecnologico dei Beni Culturali di Crotone in Calabria, Distretto ad Alta Tecnologia per i Beni Culturali in Campania (DATABENC), Distretto Tecnologico per i Beni Culturali del Lazio.

\section{Cultural district}

A network of regional relevance made of enterprises and cultural institutions belonging to a same territory that operate in the cultural heritage field and in the connected production chains, creating horizontal and hierarchic relations, pursuing internal, external and multiple integration in the public domain. The following networks respond to the cultural district model: Distretto Culturale della Valle Camonica, Distretto Dominus - Oltrepo' Mantovano, Distretto Le Regge dei Gonzaga, Distretto Culturale di Monza e Brianza, Distretto Culturale della Provincia di Cremona, Distretto Culturale della Valtellina, Distretto Culturale Evoluto delle Marche.

\section{System-wide cultural district}

A network of regional, national, and international relevance made of enterprises and cultural institutes heterogeneous for specialization but belonging to the same territory, that operate in the cultural heritage chain and in the connected production chains, creating vertical, horizontal and transversal relations, pursuing internal, external, and multiple integration. The following networks respond to the SWCD model: Distretto per le tecnologie dei beni culturali e della città sostenibile (DiTBeCs), Distretto Puglia Creativa.

\section{Meta-district}

A network of regional, national and international relevance made of enterprises and cultural institutes heterogeneous for specialization that strongly rely on ICT to carry out the common activities. It operates in the cultural heritage chain and the connected productive chains, creating horizontal and vertical relations, pursuing internal, external, and multiple integration. The Meta-distretto Veneto dei Beni Culturali e Ambientali responds to this model.

The district partners generally include wide territorial networks of local stakeholders (research infrastructures, associations, foundations, consortia, etc.) while the SWCDs are not present. An exception is represented by the Distretto Culturale Evoluto Piceno which is an operative branch of the Distretto Culturale Evoluto delle Marche but this link is established ex lege by the regional 


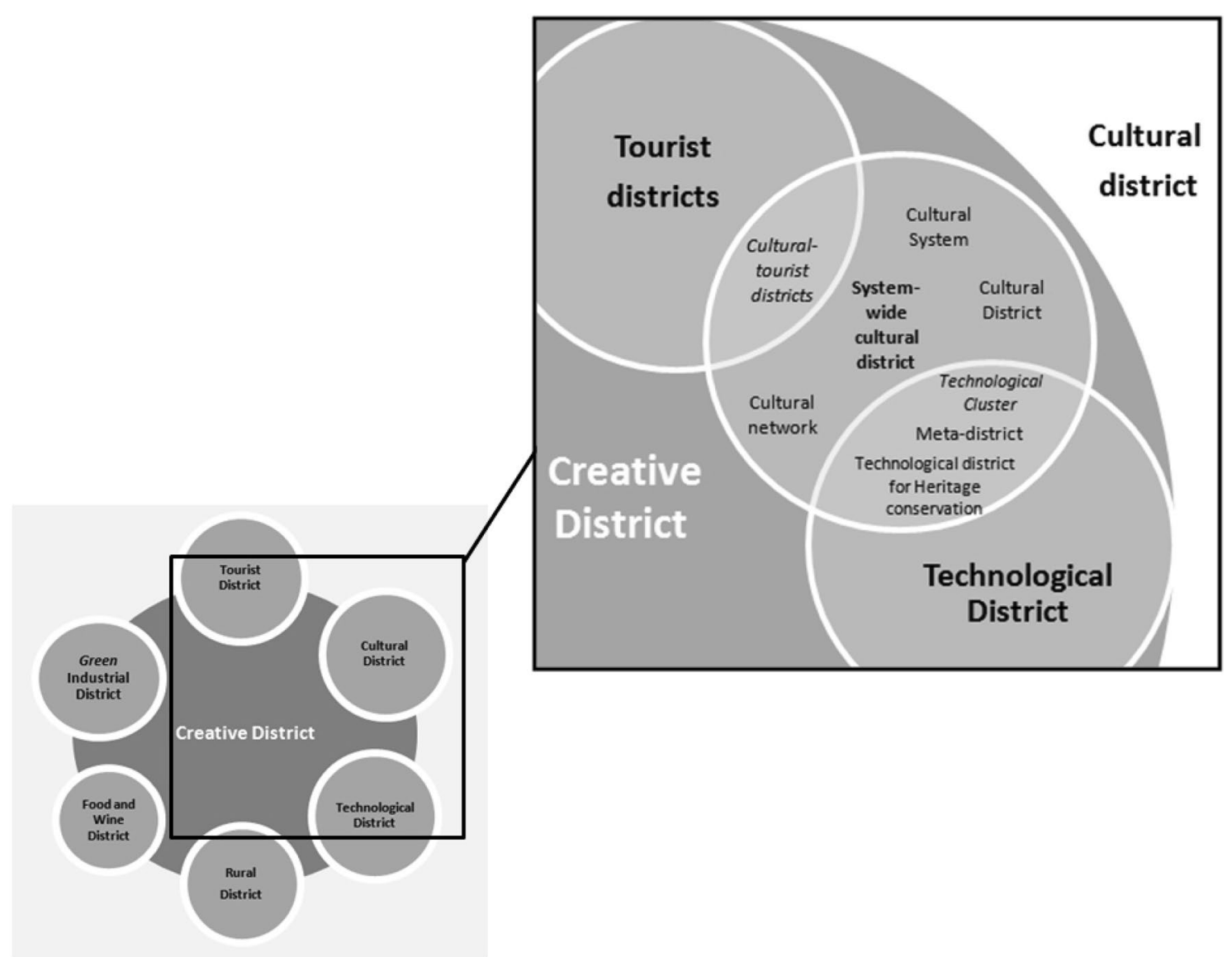

Fig. 2 The ecosystem model applied to SMEs in economic studies on innovation and to cultural/creative ecosystems: the cultural district as an umbrella concept (Source: elaboration of the authors)

law on cultural districts. Furthermore, an institutionalized and institutional vision of the cultural district links the creation of supra-local clusters to the internationalization policies adopted by public administrations. Our framework has been particularly useful to confirm this tendency.

In the field "Typology" of Tables 5, 6, 7, 8 and 9 all districts are "planned" or "semi-planned". While, the combined use of the "Structure" and "Implementation of the district project at 2019" fields, shows that only ten districts are still operational today and, where it happens, it is thanks to an evolution of the management structure and nodes, supported by regional laws or new calls of banking foundations but, more important, by enrolling actors, fact-building and circulating translations (Arnaboldi and Spiller 2011). To sum up, Italian SWCDs do not present the nested geographies peculiar of EEs. On the national scene and, in particular, in regional policies for culture and creativity, the cultural district represents an umbrella concept under which the networks illustrated in Table 10 are located (see Fig. 2).
This scenario is partially due to the precariousness of the political context which has slowed and limited the State's action, has delayed the expenditure for the 2007-2013 programming, has created the continuous redistribution of the responsibilities of the various Ministries (the Ministry of Culture that became Ministry of Culture and Tourism, the birth of the Ministry and Agency for Territorial Cohesion, etc.), has continued the long-standing dispute regarding the use of emergency decrees instead of the use of proper channels (Barbati 2013; Ponzini et al. 2014). However, the main reason is a myopic focus on agency of the public sector and financial institutions by scholars and policy makers, the same pointed out by Brown and Mason (2017) for EEs, which can be counteracted applying the ANT rules in the management of the district policy networks (Ponzini 2009; Arnaboldi and Spiller 2011).

Regarding the links between cultural districts and urban planning, Italian Regions consider the cultural and creative industries firstly as an economic sector to develop. As a consequence, the economic purpose of 
projects prevails on the social one and an institutional intervention, more or less marked, is expected as outlined by Santagata $(2002,2006,2010)$. However, the social fabric remains the keystone that keeps the Italian production system together, even in the cultural and creative field where SMEs are linked by personal or family ties. For this reason, the authority-led initiatives try to include local identity in the regeneration projects through a participative planning of goals and interventions, using the approach identified in Europe, Canada and Australia by Ferilli et al. (2016) and Girard et al. (2016). To sum up, the district model prevails over the cluster one but, compare to other countries, it is conceived mainly as a policy-making result and it focuses on physical assets recovery (Ponzini et al. 2014; Sacco et al. 2013b). In this view, the framework we propose offers a more detailed picture about the district management structure and nodes and their evolution over time, opening new perspective regarding the understanding of the links established by cultural networks in the hosting cities and, in particular, regarding their management in the policies for the historical urban landscape, encouraging similar studies under the lens of the EEs model and the ATN rules in other countries.

\section{Abbreviations}

EEs: entrepreneurial ecosystems; SMEs: small and medium enterprises; SWCDs: system-wide cultural districts; MIUR: Italian Ministry of Education; NOP: National operative programme; ROP: Regional operative programme.

\section{Acknowledgements}

Not applicable.

\section{Authors' contributions}

The manuscript has been jointly written by the authors in all parts. Both authors read and approved the final manuscript.

\section{Funding}

This work has been financially supported by the Fondazione Banco di Sardegna under the Research project "Cultural Districts in Sardinia Region. A toolkit for the Cultural Heritage and Landscape Governance".

\section{Availability of data and materials}

Not applicable.

\section{Competing interests}

The authors declare that they have no competing interests.

Received: 23 September 2019 Accepted: 14 January 2020

Published online: 30 January 2020

\section{References}

Alberti FG, Giusti JD (2009) Alla ricerca dei distretti culturali: un analisi critica della letteratura. Liuc paper Serie management ed economia della cultura 2(229):1-31

Arnaboldi M, Spiller N (2011) Actor-network theory and stakeholder collaboration: the case of cultural districts. Tour Manag 32(3):641-654

Barbati C (2013) II rilancio dello spettacolo nelle scelte urgenti del decreto "Valore cultura". Aedon- Rivista di arti e diritto on line 3:9-19
Barbetta GP, Cammelli M, Della Torre S (eds) (2013) Distretti culturali: dalla teoria alla pratica. II Mulino, Bologna, pp 21-66

Bauman Z (1998) On glocalization: or globalization for some, localization for some others. Thesis Eleven 54:37-49

Belussi F, Staber U (eds) (2011) Managing networks of creativity. Routledge, London, pp 30-45

Bertacchini E, Segre G (2016) Culture, sustainable development and social quality: a paradigm shift in the economic analysis of cultural production and heritage conservation (Special Issue). City Cult Soc 7:69-70

Brown R, Mason C (2017) Looking inside the spiky bits: a critical review and conceptualisation of entrepreneurial ecosystems. Small Bus Econ 49:11-30

Camerlengo Q (2013) Analisi del quadro normativo-istituzionale per i distretti culturali. In: Francesconi A, Cioccarelli G (eds) Organizzare i distretti culturali evoluti. Franco Angeli, Milano, pp 169-242

Carta M (2003) Pianificare nel dominio culturale. Strutture e strategie per I'armatura culturale in Sicilia. Dipartimento Città e Territorio, Università di Palermo, Palermo

Colavitti AM (2018) Urban heritage management planning with history. Springer, Cham- $\mathrm{CH}$

Colavitti AM, Usai A (2014) Federalismo demaniale e autonomie locali: gli strumenti per regolare i rapporti interistituzionali nel trasferimento dei beni costieri appartenenti al ministero della Difesa. Aedon 2

Colavitti AM, Serra S, Usai A (2018) Locus amoenus. Pianificare il patrimonio culturale per una nuova geografia dello sviluppo. Altralinea, Firenze

Comunian R, Chapain C, Clifton N (2014) Creative industries \& creative policies: a European perspective? (Special Issue). City Cult Soc 5:51-53

Council of Europe (2000) European landscape convention, Florence, 20.X.2000. ETS no.176, art.1 letter e.

Della Corte V, Del Gaudio G, Sepe F, D'Andrea C (2018) Innovation in cultural districts: the cases of Naples and Washington. In: Dominici G, Del Giudice M, Lombardi R (eds) Governing business systems: theories and challenges for systems thinking in practice. Springer, Cham- $\mathrm{CH}$, pp 153-166

Esposito CR, Rigby DL (2018) Buzz and pipelines: the costs and benefits of local and nonlocal interaction. J Econ Geogr 19(3):753-773. https://doi. org/10.1093/jeg/lby039

Feiock CR, Jae Moon M, Park HJ (2008) Is the world "Flat" or "Spiky"? Rethinking the governance implications of globalization for economic development. Public Adm Rev 68(1):25-35

Ferilli G, Sacco PL, Tavano Blessi G (2016) Cities as creative hubs: from instrumental to functional values of culture-led local development. In: Girard LF, Baycan T, Nijkamp P (eds) Sustainable city and creativity: promoting creative urban initiatives. Routledge, London, pp 245-270

Ferilli G, Sacco PL, Tavano Blessi G, Forbici S (2017) Power to the people: when culture works as a social catalyst in urban regeneration processes (and when it does not). Eur Plann Stud 25(2):241-258. https://doi. org/10.1080/09654313.2016.1259397

Florida R (2002) The rise of the creative class: and how it's transforming work, leisure and everyday life. Basic Books, New York

Girard LF, Baycan T, Nijkamp P (eds) (2016) Sustainable city and creativity: promoting creative urban initiatives. Routledge, London

Habersetzera A, Grèzes-Bürcherb S, Boschma R, Mayera H (2018) Enterpriserelated social capital as a driver of firm growth in the periphery? J Rural Stud 65:143-151. https://doi.org/10.1016/j.jrurstud.2018.10.009

Hinna A, Seddio P (2013) Imprese, risorse e sviluppo: ipotesi e dibattito intorno ai distretti culturali. In: Barbetta GP, Cammelli M, Della Torre S (eds) Distretti culturali: dalla teoria alla pratica. II Mulino, Bologna, pp 21-66

Howkins J (2010) Creative ecologies: where thinking is a proper job. Queensland University Press, Queensland

Hutton TA (2016) Cities and the cultural economy. Routledge, London

Kern P, Montalto V (2013) Europa e cultura: quali risorse per il periodo 2014-2020? In: Grossi R (ed) Una strategia per la cultura una strategia per il paese: IX Rapporto annuale Federculture 2013. II Sole24Ore, Milano, pp 73-88

Kim U, Aguilera RV (2015) The world is spiky: an internationalization framework for a semi-globalized world. Glob Strategy J 5:113-132

Lazzeretti L (2012) Cluster creativi per i beni culturali: L'esperienza toscana dalle tecnologie per la conservazione e valorizzazione. Firenze University Press, Firenze

Lazzeretti L (ed) (2013) Creative industries and innovation in Europe: concepts, measures and comparative case studies. Routledge, London 
Markwick M (2018) Creative clusters in the regeneration of Valletta and the cultural politics of Strait Street. Urban Res Pract 11(2):87-110. https://doi. org/10.1080/17535069.2017.1296180

Mercer C (2008) Bergen and beyond: the role of municipalities, cities, and cityregions in developing the creative economy. In: Mercer C (ed) Hands-on: regional strategies for creative industries in Bergen, Tartu and Turku. Nordic Innovations Centre (NICe) and City of Tartu, Estonia. http://www. luts.ee/kjoomla/creativeindustriespublication/publication.pdf. Accessed 12 June 2016

Montella M (ed) (2015) Distretti culturali: esperienze a confronto. II capitale culturale. Studies on the Value of Cultural Heritage Supplementi 3

Mudambi R, Li L, Ma X, Makino S, Qian G, Boschma R (2018) Zoom in, zoom out: geographic scale and multinational activity. J Int Bus Stud 49:929-941

Nuccio M, Ponzini D (2017) What does a cultural district actually do? Critically reappraising 15 years of cultural district policy in Italy. Eur Urban Reg Stud 24(4):405-424. https://doi.org/10.1177/0969776416643749

OECD (2005) Culture and local development. OECD Publishing, Paris Cedex

Palmi P (2013) Le fabbriche della creatività: Un'analisi organizzativa dei distretti evoluti. Franco Angeli, Milano

Ponzini D (2008) II territorio dei beni culturali: Interpretazioni strategiche del processo di privatizzazione dei beni e delle attività culturali in Italia. Carocci Editore, Roma

Ponzini D (2009) Urban implications of cultural policy networks: the case of the Mount Vernon Cultural District in Baltimore. Environ Plan C Gov Policy 27(3):433-450

Ponzini D (2016) Cultural policy-making by networking. In: Hristova S, Dragićević Šešić M, Dragi Evi M, Duxbury N (eds) Culture and sustainability in European cities: imagining Europolis. Routledge, London, pp 100-109

Ponzini D, Gugu S, Oppio A (2014) Is the concept of the cultural district appropriate for both analysis and policymaking? Two cases in Northern Italy. City Cult Soc 5:75-85

Porter ME (1990) The competitive advantage of nations. The Free Press, New York

Porter ME (2003) The economic performance of regions. Reg Stud $37(6-7): 549-578$

Robertson R (1992) Globalization: social theory and global culture. SAGE, London

Sacco PL (2011) Culture 3.0: a new perspective for the EU 2014-2020 structural funds programming. http://www.gepac.gov.pt/gepac-dsepac/estud os-e-estatisticas/estudos/0408-culture-30-a-new-perspective-for-the-eu2014-2020-pdf.aspx. Accessed 08 Sept 2016

Sacco PL, Ferilli G (2006) II distretto culturale evoluto nell'economia post industriale. DADI Working papers 4:1-28

Sacco PL, Pedrini S (2003) II distretto culturale: mito o opportunità? II Risparmio 51(3):101-155

Sacco PL, Tavano Blessi G (2006) Verso un nuovo modello di sviluppo sostenibile: distretti culturali e aree urbane. DADI Working papers 6

Sacco PL, Ferilli G, Lavanga M (2006) The cultural district organizational model: a theoretical and policy design approach. DADI, Università IUAV, Venezia

Sacco PL, Ferilli G, Tavano Blessi G (eds) (2013a) Cultura e sviluppo locale: verso il Distretto culturale evoluto. II Mulino, Bologna

Sacco PL, Ferilli G, Tavano Blessi G, Nuccio M (2013b) Culture as an engine of local development processes: system-wide cultural districts I: theory. Growth Change 44(4):555-570
Sacco PL, Ferilli G, Tavano Blessi G, Nuccio M (2013c) Culture as an engine of local development processes: system-wide cultural districts II: prototype cases. Growth Change 44(4):555-570

Sager T (2011) Neo-liberal urban planning policies: a literature survey 1990-2010. Progr Plan 76(4):147-199

Salvemini S (2008) I neodistretti industriali tra nuova cultura e antico territorio. Econ Manag 3:3-10

Santagata W (2000) Distretti culturali, diritti di proprietà e crescita economica sostenibile. Rassegna economica Banco di Napoli 64(1):31-61

Santagata W (2002) Cultural districts, property rights and sustainable growth. Int J Urban Reg Res 26(1):9-23

Santagata W (2006) Cultural districts and their role in developed and developing countries. In: Ginsburgh V, Throsby D (eds) Handbook of the economics of art and culture. Elsevier, Amsterdam, pp 1101-1119

Santagata W (2010) The culture factory: creativity and the production of culture. Springer, Berlin

Scott AJ (2014) Beyond the creative city: cognitive-cultural capitalism and new urbanism. Reg Stud 48(4):565-578

Seddio P (2013) La gestione integrata di reti e sistemi culturali: Contenuti, esperienze e prospettive. Franco Angeli, Milano

Sen A (1992) Inequality reexamined. Harvard University Press, Cambridge Massachusetts

Sen A (1999) Development as freedom. Oxford University Press, Oxford

Stevenson D (2014) Cities of culture: a global perspective. Routledge, Oxon

Throsby D (2001) Economics and culture. Cambridge University Press, Cambridge

Trigilia C (2014) Relazione sull'attività svolta e sulle azioni in corso: Ministro per la coesione territoriale, 20 febbraio 2014. http://www.coesioneterritoriale .gov.it/relazione-sullattivita-svolta-e-sulle-azioni-in-corso/. Accessed 10 May 2014

Usai A (2016a) II distretto culturale evoluto, Beni culturali e pianificazione del territorio nella sfida futura. Altralinea Edizioni, Firenze

Usai A (2016b) The creative city: cultural policies and urban regeneration between conservation and development. P.I.E. Peter Lang, Brussels

Valentino PA (2001) I distretti culturali: Nuove opportunità di sviluppo del territorio. Associazione Civita, Roma

Valentino PA (2003) Le trame del territorio: politiche di sviluppo dei sistemi territoriali e distretti culturali. Sperling \& Kupfer, Milano

Valentino PA, Musacchio A, Perego F (1999) La storia del futuro: Beni culturali, specializzazione del territorio e nuova occupazione. Giunti, Firenze

Wellman B, Hampton K (1999) Living networked on and offline. Contemp Sociol 28(6):648-654

Wellman B, Hampton K (2002) The not so global village of Netville. In: Wellman B, Haythornthwaite C (eds) The internet in everyday life. Blackwell, Oxford, pp 345-371

\section{Publisher's Note}

Springer Nature remains neutral with regard to jurisdictional claims in published maps and institutional affiliations. 